\title{
ARTYKUtY
}

Klio. Czasopismo poświęcone dziejom Polski i powszechnym

PL ISSN 1643-8191, t. 53 (2)/2020, s. 19-66

(c) $(1)$

JACEK WiJACZKA*

\section{Próba zimnej wody (pławienie) w procesach o czary we uczesnonowożytnej Europie}

\section{A cold water ordeal in witchcraft cases in early modern Europe}

Streszczenie: Artykuł jest podsumowaniem dotychczasowego stanu wiedzy na temat próby zimnej wody (pławienie) stosowanej w procesach o czary we wczesnonowożytnej Europie. Autor przedstawia, na konkretnych przykładach, w jaki sposób próba wody była przeprowadzana w poszczególnych krajach europejskich. Wskazuje na podobieństwa i różnice. Jednoznacznie jednak widać, że wiara w „sprawiedliwość” tej próby była powszechna i akceptowana w społeczeństwie europejskim, niezależnie od wyznania. I to dzięki temu powszechnemu przekonaniu, mimo że prawnie zakazana już w średniowieczu, była koronnym dowodem na to, czy ktoś jest czarownica, czy też nie. Nie wszyscy sędziowie akceptowali tę próbę, ale byli oni w zdecydowanej mniejszości. Próba zimnej wody stosowana była na różnych etapach oskarżenia o czary, co, jak się wydaje, zależało od lokalnej tradycji.

Katedra Historii Nowożytnej i Krajów Niemieckich, Instytut Historii i Archiwistyki, ul. Władysława Bojarskiego 1, 87-100 Toruń, jawi@umk.pl, ORCID: 0000-0003-4546-6878 . 
Abstract: The paper is a resume of the state of the art about the topic of cold water ordeals applied to the witchcraft court cases in an early modern Europe. Author presents case studies to explain the ordeal in different parts of Europe. Regional differences and similarities are highlighted. Nevertheless, a main conclusion is that belief in "justice" of this ordeal was common and accepted among European society, despite a confession. This universal and widespread belief resulted in trusting the ordeal despite it was forbidden since medieval times. A result of a cold water ordeal indicated a witch or denied witchcraft accusations. Not every judge accepted the ordeal, however the sceptics were an insignificant minority. A cold water ordeal could be applied during a whole process, at different phases of a trial; it depended on local tradition in this respect.

Słowa kluczowe: próba wody, procesy o czary, czarownice, czarownicy, wczesna nowożytność, Europa, Rzesza Niemiecka

Keywords: trial by water, witch trials, witches, magicians, early modern period, Europe, German Reich

\section{Uwagi ustępne}

W potocznej świadomości historycznej próba zimnej wody, popularnie zwana pławieniem, kojarzy się jednoznacznie z procesem o czary, jako jeden ze stałych jego elementów. Wynika to m.in. z tego, że w ramach kilku tysięcy pozycji dotyczących procesów o czary, które zostały przeprowadzone w XVI-XVIII w., wspominana jest dosyć często ${ }^{1}$. Na dodatek $\mathrm{w}$ pracach tych często pojawiają się ilustracje ją przedstawiające. Mimo to

${ }^{1}$ Choć trzeba też zauważyć, że nie ma o niej wzmianki w niektórych syntezach dotyczących procesów o czary w czasach wczesnonowożytnych. Nie znajdujemy o niej choćby jednego słowa w pracy: B. Ankarloo, S. Clark, W. Monter, The period of the witch trials $(=$ „Witchcraft and Magic in Europe”, vol. 4), eds. B. Ankarloo, S. Clark, Philadelphia 2002. 
jak dotąd ukazało się jedynie kilka artykułów poświęconych wyłącznie tej próbie ${ }^{2}$.

Prezentowany artykuł jest podsumowaniem dotychczasowego stanu wiedzy na temat stosowania próby wody w europejskich procesach o czary w XVI-XVIII w. i nie rości sobie pretensji do wyczerpania tematu.

\section{Początek stosowania próby zimnej wody}

Początek stosowania próby pławienia oraz powód, dla którego była wykorzystywana w związku z oskarżeniami o czary, niknie w pomroce dziejów. Wiadomo jednak, że już w najstarszym znanym nam spisanym i zachowanym zbiorze prawa, tzw. Kodeksie Ur-Nammu, sporządzonym ok. 2100 r. p.n.e. w Mezopotamii, jeden z paragrafów (nr 13) stwierdzał, że aby udowodnić komuś winę, można użyć próby pławienia w rzece. Jeśli oskarżona osoba w trakcie pławienia $\mathrm{w}$ rzece okaże się niewinna, to oskarżyciel ma

2 R. Zguta, The ordeal by water (swimming of witches) in the East Slavic world, „Slavic Review” 1977, vol. 36, no. 2, s. 220-230; H. Grössing, Trägheit und Auftrieb - Hexenflug und Wasserprobe, „Österreichische Ingenieur- und Architektenzeitung” 1990, H. 10, s. 484-487; G. Gersmann, Wasserproben und Hexenprozesse. Ansichten der Hexenverfolgung im Fürstbistum Münster, „Westfälische Forschungen” 1998, Bd. 48, s. 449-479; idem, Skizze einer Geschichte der Wasserprobe, w: Wasser, Hrsg. B. Busch, L. Förster, Bonn 2000, s. 157-167; H. Pihlajamäki, Swimming the itch, pricking for the Devil's mark: ordeals in the early modern witchcraft, "Journal of Legal History" 2000, vol. 21, no. 2, s. 35-58; P. A. Heuser, Eine Auseinandersetzung über den Indizienwert der Kaltwasserprobe im Hexenprozeß. Studien zur Rick-Delrio-Kontroverse 1597-1599 und zur Zurückdrängung der Kaltwasserprobe aus kurkölnischen Hexenprozessen im 17. Jahrhundert, „Rheinisch-westfälische Zeitschrift für Volkskunde” 2000, Bd. 45, s. 73-135; G. Gersmann, „Wasserproben und Hexenprozessen im frühneuzeitlichen Fürstbistum Münster”, 2000 (niepublikowana rozprawa habilitacyjna); idem, Von schwemmern und sinkern. Hexenverfolgungen und Wasserproben in der münsterländischen Herrlichkeit Lembeck, w: Alltagsleben und Magie in Hexenprozessen, Hrsg. R. Voltmer, G. Gehl, Weimar 2003, s. 95-106; P. Tóth, River ordeal-trial by water-swimming of witches: procedures of ordeal in witch trials, w: Witchcraft mythologies and persecutions, eds. G. Klaniczay, E. Pòcs, in collab. E. Csonka-Takács, Budapest-New York 2008, s. 129-163; J. Wijaczka, Próba zimnej wody (ptawienie) w oskarżeniach i procesach o czary w państwie polsko-litewskim w XVI-XVIII wieku, „Odrodzenie i Reformacja w Polsce” 2016, t. 60, s. 73-109. 
zapłacić grzywnę w wysokości trzech srebrnych szekli3 ${ }^{3}$. Nie chodziło tu jednak o udowodnienie przestępstwa czarostwa, ponieważ próba wody została wspomniana przy okazji przestępstw o charakterze seksualnym ${ }^{4}$. Natomiast już w tzw. Kodeksie Hammurabiego, władcy Mezopotamii w latach 1792-1750 p.n.e., próba wody była wymieniona w związku z przestępstwem czarów. W kodeksie tym bowiem zapisano, że gdy osoba oskarżająca nie mogła przedstawić namacalnych dowodów winy, to wówczas oskarżona osoba była poddawana próbie pławienia przeprowadzanej w rzece. W przypadku, gdy próba wypadła pomyślnie dla oskarżonego, oskarżyciel zostawał zabity, a jego majątek przejmowała osoba niesłusznie pomówiona. W sytuacji, gdy próba wypadła po myśli oskarżyciela, to on z kolei przejmował majątek ${ }^{5}$.

Chaldejczcy używali natomiast wody jako obrony przed demonami. Jedno z tamtejszych bóstw poproszone o ochronę przed demonami zadającymi choroby poradziło ludziom, że należy wziąć pełne wiadro wody, nadać jej czystość za pomocą zaklęcia i spryskać głowę chorej osoby ${ }^{6}$. Podobne zastosowanie wody przeciwko złym demonom znali Finowie, którzy przynieśli te obyczaje do Europy.

\section{Próba zimnej wody u średniowieczu}

Dla chrześcijanina woda była i jest początkiem życia. W trakcie chrztu poświęcona woda zmywa z niemowlaka grzech pierworodny. W związku

3 Law collections from Mesopotamia and Asia Minor, ed. M. T. Roth, in collab. H. A. Haffner Jr., Atlanta 1995, s. 18: „If a man accusses another man of [...] and he has him brought to the divine River Ordeal but the divine River Ordeal clears him, the one who had him brought (i.e. the accuser) [...] shall weigh and deliver 3 shekels of silver".

4 Ibidem, s. 21-22, przypis 12.

5 Ibidem, s. 81: „If a man charges another man with practicing witchcraft but cannot bring proof against him, he who is charged with witchcraft shall go to the divine River Ordeal, he shall indeed submit to the divine River Ordeal; if the divine River Ordeal should overwhelm him, his accuser shall take full legal possession of his estate; if the divine River Ordeal should clear that man and should he survive, he who made the charge of witchcraft against him shall be killed; he who submitted to the divine River Ordeal shall take full legal possession of his accuser's estate".

6 E. Kiessling, Zauberei in den germanischen Volksrechten, Jena 1941, s. 15. 
z tym w średniowiecznym procesie karnym, a także cywilnym, próba zimnej wody (judicum aquae frigidae, proba aquae frigidae) stała się jednym ze środków dowodowych, będących elementem ordaliów, czyli sądów bożych, mających dowieść winy lub niewinności osoby oskarżonej o popełnienie przestępstwa. Najpopularniejszymi średniowiecznymi ordaliami były pojedynki, próba żelaza i próba wody - gorącej lub zimnej ${ }^{7}$. Pójście pod wodę stanowiło niezaprzeczalny dowód niewinności, ponieważ w świecie chrześcijańskim powszechnie wierzono, że woda, uświęcona przez chrzest Chrystusa w Jordanie, nie przyjęłaby żadnego przestępcy, a Bóg nie pozwala na skrzywdzenie niewinnej osoby ${ }^{8}$.

Z biegiem lat ordalia jednak zaczęły budzić wątpliwości. $Z$ tego powodu wprowadzano pewne ograniczenia w ich stosowaniu. W 829 r. cesarz Ludwik I zwany Pobożnym (813-840) pozwolił na przeprowadzanie pławienia jedynie w chrześcijańskim rycie ustalonym przez papieża Eugeniusza II (824-827) .

Stosowanie próby zimnej wody jest odnotowane m.in. w „Zwierciadle saskim" (Sachsenspiegel), spisie prawa zwyczajowego z terenu Saksonii powstałego w pierwszej połowie XIII w., w którym odnotowano, że próbę tę wykorzystywano w celu rozstrzygnięcia wątpliwości w konfliktach o prawo własności i w sporach granicznych. Według Hermanna Nottorpa próba zimnej wody nie była wówczas jeszcze przypisana do jednego typu przestępstw, najczęściej używano jej w przypadkach kradzieży i herezji, choć w 1090 r. w miejscowości Vötting koło Freising (dzisiaj dzielnica tego miasta) została zastosowana wobec trzech kobiet oskarżonych o czarostwo ${ }^{10}$. Aresztowane kobiety obwiniono o szkodzenie ludziom za pomocą trucizny oraz zniszczenie plonów za pomocą czarów pogodowych. Natychmiast po pojmaniu poddano je próbie zimnej wody, która nie dowiodła ich rzekomej winy (tonęły). Następnie pobito je, aby uzyskać przyznanie się do winy. Kobiety do stawianych im zarzutów jednak się nie przyznały. Przewieziono

7 R. Bartlett, Trial by fire and water. The medieval judicial ordeal, Oxford 1986, passim.

8 Swimming, w: J. B. Durant, M. D. Bailey, Historical dictionary of witchcraft, Lanham-Toronto-Plymouth 2012, s. 187.

${ }^{9}$ H. Brunner, Deutsche Rechtsgeschichte, Bd. 2, Leipzig 1892, s. 411; por. G. Gersmann, Skizze einer Geschichte der Wasserprobe, s. 158.

${ }^{10}$ H. Nottarp, Gottesurteilstudien, München 1956, s. 162. 
je do Freising, gdzie zostały ponownie pobite. Ponieważ tym razem także nie przyniosło to pożądanego przez tłum skutku, kobiety przewieziono nad brzeg Izery, gdzie zostały spalone. Później postępowanie wobec nich uznano za bezprawne, a prochy pochowano w poświęconej ziemi w obrębie murów klasztoru Weihenstephan ${ }^{11}$.

Próba zimnej wody była stosowana w średniowieczu - zarówno na zachodzie, jak i na wschodzie Europy. W procesach o czary była wykorzystywana na terenie państwa moskiewskiego już w XI w. ${ }^{12}$, a w XII i XIII w. także na terenach zamieszkałych przez wschodnich Słowian ${ }^{13}$. Z 1153 r. pochodzi informacja zapisana przez arabskiego podróżnika nazwiskiem Abu Hamid al.-Gharanti (ok. 1080-ok. 1169), twierdzącego, że co 20 lat w Kijowie dochodziło do oskarżeń kierowanych pod adresem starych kobiet, którym zarzucano, że za pomocą czarów czynią szkody ludziom. Kobiety te zaciągano nad rzekę - prawdopodobnie Dniepr - pławiono, a jeśli utrzymywały się na powierzchni wody, to uznawano je winnymi i palono ${ }^{14}$. Natomiast w Norwegii i Hiszpanii w XII w. obowiązujące przepisy prawne zalecały stosowanie $\mathrm{w}$ procesach o czary nie próbę zimnej wody, lecz gorącego żelaza ${ }^{15}$.

Do XIII w. panowało powszechne przekonanie, że ordalia dostarczają jednoznacznego dowodu winy lub niewinności oskarżonej osoby ${ }^{16}$. Krytyka sądów bożych pojawiała się jednak coraz częściej, także w środowisku katolickich intelektualistów - szczególnie w XII w. ${ }^{17}$ Zapewne krytyka ta sprawiła, że z inicjatywy papieża Innocentego III (1198-1216) w trak-

11 Ibidem; W. Behringer, Witches and witch-hunts. A global history, Cambridge 2004, s. 55.

12 R. Zguta, Witchcraft trials in seventeenth-century Russia, „The American Historical Review” 1977, vol. 82, no. 5, s. 1188-1189. W czasach wczesnonowożytnych w procesach o czary przeprowadzanych w państwie moskiewskim (Rosji) próby tej nie stosowano; ibidem, s. 1189.

13 K. Moszyński, Kultura ludowa Stowian, t. 2: Kultura duchowa, cz. 1, Warszawa 1967, s. 646.

14 R. Zguta, The ordeal by water..., s. 222; W. Behringer, op. cit., s. 56.

15 R. Bartlett, op. cit., s. 144.

16 H. Nottarp, op. cit., s. 392.

17 J. W. Baldwin, The intellectual preparation for the canon of 1215 against ordeals, „Speculum” 1961, vol. 36, no. 4, s. 613-636. 
cie IV Soboru Laterańskiego w 1215 r. podjęto decyzję o zakazie udziału duchownych w sądach bożych ${ }^{18}$. Kilka lat później, w 1222 r., papież Honoriusz III (1216-1227) zabronił wójtom i sędziom świeckim stosowania ordaliów na terenie państwa zakonu niemieckiego w Inflantach, grożąc im karami kościelnymi za nieprzestrzeganie zakazu ${ }^{19}$. Ten papieski nakaz od 1234 r. stał się obowiązujący na terenie całego Kościoła katolickiego, dzięki wprowadzeniu go przez papieża Grzegorza IX (1227-1241) do zbioru prawa zw. Liber Extra ${ }^{20}$.

W ślady papieży poszli świeccy władcy. Król duński Waldemar II Zwycięski (1202-1241) już w 1216 r., a więc rok po IV Soborze Laterańskim, zabronił w ogóle używania ordaliów w rządzonym przez siebie $\mathrm{kraju}^{21}$. W Anglii ordalia zostały zakazane w 1219 r. $^{22}$ Cesarz Fryderyk II (1220-1250) w 1231 r. zabronił sędziom w Królestwie Sycylii przeprowadzania sądów bożych - twierdząc, że są sprzeczne z naturalnym porządkiem rzeczy i prawdą 23. Wkrótce dołączyła Hiszpania, w której ordalia zostały zakazane w $1247 \mathrm{r}^{24}$

W związku z tymi zakazami, które wyszły tak ze strony kościelnej, jak i świeckiej, w ostatnich stuleciach średniowiecza ordalia teoretycznie powinny przestać być stosowane - zarówno przez kościelne, jak i świeckie

18 „Nikt też nie może udzielić błogosławieństwa ani poświęcenia [stosowanego przy tzw. sądach bożych] rytu oczyszczenia lodowatą lub wrzącą wodą albo rozpalonym żelazem”; Dokumenty soborów powszechnych. Tekst grecki, tacinski, polski, t. 2: (869-1312) Konstantynopol IV, Lateran I, Lateran II, Lateran III, Lateran IV, Lyon I, Lyon II, Vienne, oprac. ks. A. Baron, ks. H. Pietras SJ, Kraków 2003, s. 257.

19 H. Nottarp, op. cit., s. 352.

20 W. Trusen, Das Verbot des Gottesurteile und der Inquisitionsprozeß. Zum Wandel des Strafverfahrens unter dem Einfluß des gelehrten Rechts im Spätmittelalter, w: Sozialer Wandel im Mittelalter. Wahrnehmungsformen, Erklärungsmuster, Regelungsmechanissmen, Hrsg. J. Miethke, K. Schreiner, Sigmaringen 1994, s. 238.

21 R. Bartlett, op. cit., s. 100.

22 Ibidem.

23 Ibidem, s. 142; G. Gersmann, Skizze einer Geschichte der Wasserprobe, s. 158; por. W. Stürner, Die Konstitutionen Fridrichs II. für das Königreich Sizilien, Hannover 1996.

24 R. Bartlett, op. cit., s. 100. 
sądy ${ }^{25}$. Tak się jednak nie stało, ponieważ w późnym średniowieczu ordalia miały nadal licznych zwolenników wśród dostojników kościelnych ${ }^{26}$. Próba zimnej wody była przeprowadzana m.in. w Czechach. Tamtejsi duchowni mimo zakazu soborowego brali udział w sądach bożych, w związku z czym arcybiskup Pragi przypominał o tym w 1343 r. duchownym w swej diecezji ${ }^{27}$. W 1428 r. synod prowincjonalny diecezji ryskiej pod przewodnictwem arcybiskupa Henninga Scharpenberga musiał zająć się ordaliami (próbą zimnej wody i próbą ognia), które nadal często były tam wykorzystywane. Synod zagroził ekskomuniką tym osobom, które z własnej woli będą w nich uczestniczyły lub zmuszały siłą do tego innych ${ }^{28}$. W XV w. próba wody była stosowana także w Dolnej Saksonii ${ }^{29}$, jak choćby wobec pewnej kobiety oskarżonej o czary w Hanowerze w $1436 \mathrm{r}^{30}$

\section{Sposoby przeprowadzania próby zimnej wody}

Próba zimnej wody polegała na wrzuceniu skrępowanej osoby do wody $\mathrm{w}$ rzece, stawie lub jeziorze. W średniowieczu przy wielu kościołach specjalnie budowano stawy ${ }^{31}$. Próby zimnej wody przeprowadzano także w napełnionych wodą wielkich beczkach, co było ponoć możliwe, „albowiem

25 J. H. Langbein, Prosecuting crime in the Renaissance. England, Germany, France, Cambridge, Massachusetts 1974, s. 134.

26 P. Dinzlebacher, Das fremde Mittelalter. Gottesurteil und Tierprozess, Essen 2006, s. $35-36$.

27 H. Nottarp, op. cit., s. 351.

28 Ibidem, s. 74; M. Madar, Estonia I: werwolves and poisoners, w: Early modern European witchcraft. Centres and peripheries, eds. B. Ankarloo, G. Henningsen, Oxford 1990 (reprint 2001), s. 266.

29 H. Nottarp, op. cit., s. 204.

30 W. G. Soldan, H. Heppe, Geschichte der Hexenprozesse, Bd. 1, München 1911 (reprint z 1969 r.), s. 381; J. Lehrmann, Hexenverfolgung in Hannover-Calemberg (und Calenberg-Göttingen). Vom Wahn bis zur Aufklärung, Lehrte-Hannover 2005, s. 127.

31 P. Dinzlebacher, op. cit., s. 35. 
sposób wiązania tak czyni małym człowieka, że łatwo w beczkę zmieścić się może"32.

Woda, w której dokonywano pławienia, musiała być w późnym średniowieczu poświęcona przez duchownego ${ }^{33}$.

Jak przebiegała próba zimnej wody, dowiadujemy się m.in. z najstarszego zwodu prawa polskiego, powstałego przed 1320 r., który zawiera opis takiej próby: „[...] opuszcza się obwinionego [do wody] w taki sposób, że związuje mu się ręce pod goleniami i wsuwa kij pomiędzy podkolana i ramiona, by nie mógł posługiwać się ani rękami, ani nogami. Należy mu zrobić znak na głowie, by można było poznać, czy człowiek tonie, czy pływa. Należy także przewiązać mu wokół brzucha powróz, by można było go wyciągnąć, gdyby tonął" 34 .

Podobnie krępowano osoby przed pławieniem także w krajach niemieckich $^{35}$. Około 1584 r. przeprowadzano próbę w taki sposób w okręgu sądowym Bonn. Rozebrawszy podejrzane o czary osoby do naga, zarówno mężczyzn, jak i kobiety, wiązano im ręce i nogi w taki sposób, że nie mogły wykonać żadnego ruchu. Następnie osoby te wrzucano do Renu. Pływały ponoć po wodzie jak poduszki z pierza. W związku z tym wielu członków ich rodzin, które przyglądały się tej próbie, prosiło, aby również i je pławić. Zgodzono się na to, ale w przeciwieństwie do swoich krewnych nie utrzymywały się na wodzie, ale natychmiast szły pod nią. W ten sposób przekonały się o winie swoich bliskich ${ }^{36}$.

Metoda pławienia nie ulegała zmianie przez wieki, w połowie XVIII w. biskup kijowski Józef Andrzej Załuski opisał bowiem następująco sposób

32 J. A. Załuski, Objaśnienie btędami zabobonów zarażonych oraz opisanie niegodziwości, która pochodzi sądzenia przez probe ptawienia w wodzie mniemanych czarownic, jako takowa proba jest omylna, różnemi dowodami [...]. Stwierdzone dla pożytku każdego, osobliwie sędziów, spowiedników, aby sędziowie poznali niepewność takowej próby, a spowiednicy wierzacych takim zabobonnym probom z btędów wyprowadzać mogli, Berdyczów 1766, s. 22.

33 Gottesurteil (Ordal), w: Handwörterbuch des deutschen Aberglaubens, Bd. 3, Berlin-Leipzig 1930/1931, s. 1026; Najstarszy zwód prawa polskiego, wyd. i oprac. J. Matuszewski, J. Matuszewski, Łódź 1995, s. 96.

34 Najstarszy zwód prawa polskiego, s. 98.

35 Zedlers Universal-Lexicon, Bd. 33, Leipzig-Halle 1747, szp. 693.

36 P. A. Heuser, op. cit., s. 87. 
poddawania tej próbie oskarżonych i podejrzanych: „[...] nogę prawą z lewą, lewą z prawą ręką związano, z przyczyny, aby pływać nie mogła ta osoba, z której dociec prawdy chciano, i trzymając na powrozie, wrzucano $\mathrm{z}$ mostu lub ze statku w wodę. I gdy poszedł pod wodę jakoby toną, jako naturalnie powinien związany człowiek, niemogący sobie siłą pomagać do pływania, takiego uznano za niewinnego, lecz gdy związany nie poszedł pod wodę, lecz pływał po wodzie, takiego winnym osądzano" ${ }^{37}$.

Istniały jednak regionalne różnice. Z połowy XVIII w. pochodzi inny opis próby wody stosowanej w Prusach Królewskich, mówiący, że wprawdzie wiązano ręce z nogami na krzyż, ale za to na plecach $^{38}$. Na początku XVIII w. wykształcony w Halle, a pracujący przez lata w Stargardzie (Szczecińskim) prawnik Jakob Brunnemann (1674-1735) w napisanym przez siebie traktacie demaskującym wiarę w czary i czarownice opisał pokrótce sposób krępowania osób puszczanych w trakcie próby na wodę. Dodał, że pławiona kobieta była przywiązywana do deski ${ }^{39}$. Brunnemann wspomniał, że ludzie przeprowadzają próbę zimnej wody, ponieważ przywiązują do niej dużą wagę. Natomiast żadną miarą nie mogą pojąć, że stara kobieta przywiązana do kłody drewna nie tonie, co jest przecież rzeczą jak najbardziej naturalną ${ }^{40}$. Kwestia sposobu przeprowadzania pławienia wymaga dalszych badań.

37 J. A. Załuski, op. cit., s. 21.

38 „Diselbe soll also angestellet werden, daß der Scharfrichter oder wer es sonst thut die Person, welche die Probe ausstehen soll, mit Händen und Füssen hinten auf die Rükken creuzweise bindet, und sie so ganz nackent unter das Wasser hinab stösset"; Nöthige Untersuchung etlicher vermeinten Beweise und Proben der Hexerei, w: Preußische Sammlung allerei bisher ungedruckten Urkunden, Nachrichten und Abhandlungen, Bd. 1, Danzig 1747, s. 535.

39 Aloysius Charitinus [pseudonim], Discurs von betrüglichen Kennzeichen der Zauberez. Worinnen viel abergläubische Meinungen vernunfftmäßig untersucht und verworffen [...], Stargard 1708, s. 45: „da man auf ein Bret tein altes Weib den rechten arm und linken Fuß zusammen bindet, und hernach aufs Wasser setzet”. Kolejne wydanie ukazało się w 1727 r. w Halle już pod prawdziwym nazwiskiem autora.

40 Ibidem, s. 45; por. H. Grössing, Hexen und Hexenverfolgung in wissenschaftshistorischer Sicht, Wien 1998, s. 107. 
Próba wody w XVI-XVIII w. najczęściej była przeprowadzana przez kata, jak choćby w Osnabrücku w Saksonii. Oskarżone osoby były przyprowadzane $\mathrm{z}$ więzienia, które znajdowało się wówczas $\mathrm{w}$ jednej z wież zwanej Kupmersturm (zburzona w końcu XVIII w.). Znajdowała się ona tuż nad przepływającą przez miasto rzeką Hase. Kat zabierał mającą być pławioną osobę na mały statek i wypływał na rzekę. Przed pławieniem daną osobę rozbierano do naga i przywiązywano prawą rękę do dużego palca lewej nogi, a lewą rękę do dużego palca prawej nogi. Następnie kat obwiązywał pławioną osobę dookoła brzucha liną i trzykrotnie wrzucał ją do wody ${ }^{41}$.

Nie wszędzie i nie zawsze tak jednak było. Zdarzało się, że próba wody była wykonywana przez inne osoby. W aktach procesu przeprowadzonego w sierpniu i wrześniu 1731 r. przeciw Barbarze Kostrzyninie z Polskich Brodów (obecnie Brody, wieś nad Wierzycą, niedaleko Gniewu) znajdujemy informację, że została poddana próbie wody wykonanej przez męża i rodzonego brata ${ }^{42}$. Według zeznań jednego ze świadków mąż Kostrzeniny, kilkakrotnie wyganiany z jej powodu z różnych wsi, pewnej nocy pławił ją wraz z jej rodzonym bratem, aby się przekonać, czy rzeczywiście jest ona czarownicą. Ponieważ nie utonęła, obaj się jej wyparli ${ }^{43}$. Próba wody w Szwecji była z kolei przeprowadzana, za zgodą sądu, przez krewnych podejrzewanej osoby, aby uniknęła kontaktu z katem, ponieważ dotknięcie przez kata uchodziło - w całej ówczesnej Europie - za hańbiące ${ }^{44}$. W związku z tym krewni pławionych osób woleli sami przeprowadzić pławienie, aby w przypadku udowodnienia niewinności dana osoba mogła nadal uczestniczyć w życiu lokalnej społeczności, a dotknięcie przez kata skazywałoby ją na życie na marginesie.

Zdarzało się, że oskarżyciel poddawał się dobrowolnie próbie wody wraz z osobą, którą oskarżył. Tak było m.in. w 1621 r., kiedy to w trakcie procesu o czary prowadzonego w amcie Goldberg w Meklemburgii

41 H. J. Stebel, Die Osnabrücker Hexenprozesse, Osnabrück 1997, s. 98.

42 T. Warmiński, Die Hexenprozesse im ehemaligen Polen, "Jahrbuch der Historischen Gesellschaft für den Netzedistrikt zu Bromberg” 1892, s. 70.

43 Monumenta historica dioeceseos Wladislaviensis, t. 5, Wladislaviae 1885, s. 42.

44 W. Rummel, R. Voltmer, Hexen und Hexenverfolgung in der Frühen Neuzeit, Darmstadt 2008, s. 48. 
o poddanie ich próbie pławienia poprosili wspólnie oskarżona o czary żona Achima Schmieda i oskarżający ją Heinrich Gustlaff ${ }^{45}$. Podobna sytuacja zaistniała również w 1630 r. w meklemburskim Crivitz ${ }^{46}$. W ten sposób oskarżyciel chciał dowieść winy pomówionej przez siebie osoby, wierząc, że on sam nie będzie utrzymywał się na powierzchni wody.

Trudno jednoznacznie odpowiedzieć na pytanie, ile razy oskarżoną osobę „puszczano” na wodę. W katolickim elektoracie Kolonii próba zimnej wody była powtarzana najczęściej trzykrotnie ${ }^{47}$, za trzecim razem osobę oskarżoną rzucano na wodę zazwyczaj już niezwiązaną ${ }^{48}$. W podobny sposób przeprowadzono pławienie w trakcie procesu, który toczył się w $1692 \mathrm{r}$. we wsi Młotkowo w Wielkopolsce. Pławiono tam cztery kobiety, wszystkie trzykrotnie, jedną z nich na wodę puszczano dwa razy związaną, a raz nie ${ }^{49}$.

Pławienie najczęściej odbywało się w obecności licznych gapiów. Tłumy miały przyglądać się w 1751 r. pławieniu małżeństwa Ruth i Johna Osborne'ów w jednej z angielskich miejscowości ${ }^{50}$.

\section{W ubraniu czy nago?}

W literaturze przedmiotu nie do końca dotąd jest jasne, czy pławione osoby rozbierano do naga. Bogdan Baranowski w pracy o procesach o czary w Polsce w XVII-XVIII w. napisał, że pławione kobiety nie szły pod wodę, ponieważ „kilka wełnianych spódnic i fartuchów, bufiaste rękawy i staniki początkowo pomagały domniemanej czarownicy utrzymywać

45 S. Lorenz, Aktenversendung und Hexenprozeß. Dargestellt am Beispiel der Juristenfakultät Rostock und Greifswald (1570/82-1630), Frankfurt am Main-Bern 1982, s. 448-449.

46 Ibidem, s. 449.

47 W. G. Soldan, H. Heppe, op. cit., Bd. 1, s. 381.

48 P. A. Heuser, op. cit., s. 85.

49 J. Wijaczka, Proces o czary we wsi Mtotkowo w 1692 roku. Przyczynek do polowania na czarownice w Rzeczypospolitej w XVII wieku, „Odrodzenie i Reformacja w Polsce” 2004, t. 48 , s. 164 .

50 O. Davies, The world of popular magic, w: The Oxford illustrated history of witchcraft and magic, ed. O. Davies, Oxford 2017, s. 194. 
się na powierzchni" 51 . Baranowski stwierdził także, że w źródłach nie znalazł informacji, aby kobiety przed pławieniem rozbierano do naga ${ }^{52}$. Kobiety w państwie polsko-litewskim pławiono jednak nago, choć w aktach procesów tego nie odnotowywano, ponieważ - jak się wydaje - było to dla wszystkich oczywiste. Potwierdził to w drugiej połowie XVIII w. biskup kijowski Załuski, który opisując sposób przeprowadzania próby wody, wyraźnie stwierdził, że zanim rozpoczęto pławienie, to: „Najprzód obnażano do naga" 53 .

W Rzeszy również pławione osoby, mężczyźni i kobiety, rozbierano do naga. Tak czyniono ok. 1584 r. w okręgu sądowym Bonn ${ }^{54}$. W XVII w. przed pławieniem rozbierano również do naga osoby sądzone w procesach o czary w Osnabrücku ${ }^{55}$. Fakt pławienia nago potwierdza też opis próby wody stosowanej w Prusach Królewskich. Opis ten pochodzi z połowy XVIII stulecia. Czytamy w nim m.in., że oskarżoną osobę opuszczano do wody nago, nie patrząc na płeć ${ }^{56}$.

O pozostawieniu pławionym osobom, przede wszystkim kobietom, jakiegoś odzienia wspominają jednak niektóre źródła. O ubieraniu kobiet przed pławieniem w „koszule śmiertelne” wzmiankował wójt żywiecki Andrzej Komoniecki (1658-1729), opisując proces z 1698 r., w trakcie którego próbie zimnej wody poddano dwie kobiety ze wsi Lipowa (koło Żywca $)^{57}$. Nie jest jednak pewne, że przed wrzuceniem kobiet do wody owych koszul im nie zdjęto.

51 B. Baranowski, Procesy czarownic w Polsce w XVII i XVIII wieku, Łódź 1952, s. 92; idem, O hultajach, wiedźmach i wszetecznicach. Szkice z obyczajów XVII i XVIII wieku, Łódź 1962, s. 116.

52 Idem, Procesy czarownic $w$ Polsce..., s. 92, przypis 6.

53 J. A. Załuski, op. cit., s. 21.

54 P. A. Heuser, op. cit., s. 87.

55 H. J. Stebel, op. cit., s. 98.

56 Nöthige Untersuchung etlicher vermeinten Beweise und Proben der Hexerei, w: Preußische Sammlung allerei bisher ungedruckten Urkunden..., s. 535, „und sie so ganz nackent unter das Wasser hinab stösset”.

57 A. Komoniecki, Chronografia albo Dziejopis żywiecki, wyd. S. Grodziski, I. Dwornicka, Żywiec 1987, s. 267. 
Pozostawianie kobietom koszul lub halek potwierdził Johann Zedler, autor leksykonu z połowy XVIII stulecia, w którym pisał, że mężczyzn rozbierano przy pławieniu do naga, a kobietom pozostawiano halkę $(\text { Unterrock })^{58}$. Pozostawianie pławionym osobom koszul odnotowują także Walter Rummel i Rita Voltmer ${ }^{59}$. Jak się więc wydaje, rozbieranie kobiet do naga lub pozostawianie im jakiejś koszuli w trakcie pławienia było zależne od lokalnych tradycji lub decyzji sądu. Kwestia ta wymaga dalszych badań źródłowych.

$\mathrm{Z}$ całą pewnością $\mathrm{w}$ „śmiertelne koszule” ubierano uwięzione kobiety oskarżone o czary, choć nie wiadomo, czy wszędzie. Bano się zapewne, że we własnych ubraniach mogą mieć poukrywane magiczne środki, które pomogą im choćby przetrwać tortury. Informację o zakupie takich koszul znajdujemy m.in. w rachunkach kamlarii Chełmna. Dnia 25 lipca 1638 r. kamlarz zapłacił złotówkę za „płótno na koszule dla czarownic”, a 10 grudnia tego roku kupił pięć łokci płótna - po dziewięć groszy „na koszulkę dla czarownicy" ${ }^{\prime 1}$.

\section{Rola kata}

Ogromną rolę w przebiegu próby zimnej wody odgrywał, najczęściej ją przeprowadzający, kat. W Bawarii na początku XVII w. jeden z uczestników tamtejszej dysputy na temat czarostwa słusznie zauważył, że to od złej lub dobrej woli trzymających za końce liny, którą była obwiązana pławiona osoba, zależy wynik próby wody ${ }^{62}$. Przykłady z Osnabrücka wskazują, że kat z pachołkami zaczynali mocniej trzymać liny, gdy pławiona osoba

58 Wasser-Probe, w: Grosses vollständiges Universal-Lexikon aller Wissenschafften und Künste, Bd. 53, Hrsg. J. H. Zedler, Leipzig-Halle 1747, szp. 694.

59 W. Rummel, R. Voltmer, op. cit., s. 47.

60 Archiwum Państwowe w Toruniu, Akta miasta Chełmna, sygn. 11, k. 69.

61 Ibidem, s. 79.

62 S. Riezler, Geschichte der Hexenprozesse in Bayern. Im Lichte der allgemeinen Entwicklung, Stuttgart 1896, s. 80-81. 
zaczynała iść pod wodę, uniemożliwiając jej zanurzenie się ${ }^{63}$. Pastor Simon Krüger z miasteczka Hitzacker, położonego w księstwie Lüneburg, zanotował w 1610 r., że w przeprowadzonych wówczas procesach o czary skazano na śmierć wiele niewinnych ofiar, m.in. z tego powodu, że kat w trakcie przeprowadzanych przez siebie prób zimnej wody z chęci zysku dopuścił się nadużyćc ${ }^{64}$. Podobnie, jak się wydaje, postąpił kat w trakcie próby wody przeprowadzonej w 1692 r. we wsi Młotkowo (północna Wielkopolska). Jedna z pławionych kobiet o imieniu Regina, która za pierwszym razem tonęła, a dwa razy pływała w trakcie pławienia, prosiła o kolejną próbę, twierdząc, że w trakcie jednej z nich „mnie kat pociągał stryczkiem", w związku z czym utrzymywała się na powierzchni wody ${ }^{65}$.

Nie wiemy, czy na własną prośbę, ale w 1636 r. w Osnabrücku pławiony był Johann Helmich, któremu udało się pójść pod wodę. Natychmiast został zwolniony ${ }^{66}$ i jest to jeden $\mathrm{z}$ nielicznych przypadków, kiedy próba zimnej wody zakończyła się „sukcesem” osoby oskarżonej o czary w czasach wczesnonowożytnych. Nie można tu jednak wykluczyć „,̇yczliwości” kata przeprowadzającego tę próbę.

Jak zawodna była to próba i jak wiele zależało od kata oraz jego pachołków trzymających linę, można zobaczyć na ilustracji wykonanej w Anglii w 1613 r. Kobieta była przewiązana w talii liną, której końce trzymali stojący po obu stronach stawu mężczyźni. Czy pławiona kobieta szła pod wodę, zależało przede wszystkim od stopnia napięcia przez mężczyzn liny. Na dodatek nigdzie nie było prawnie określone, przez jak długi czas ciało miało utrzymywać się na powierzchni wody ${ }^{67}$.

63 G. Gersmann, Skizze einer Geschichte der Wasserprobe, s. 163.

64 W. G. Soldan, H. Heppe, op. cit., Bd. 2, s. 62; G. Schormann, Hexenprozesse in Nordwestdeutschland, Hildesheim 1977, s. 123.

65 J. Wijaczka, Proces o czary we wsi Mtotkowo..., s. 164.

66 H. J. Stebel, op. cit., s. 97.

67 R. Schulte, Hexenverfolgung in Schleswig-Holstein vom 16.-18. Jahrhundert, Heide 2001, s. 52. 


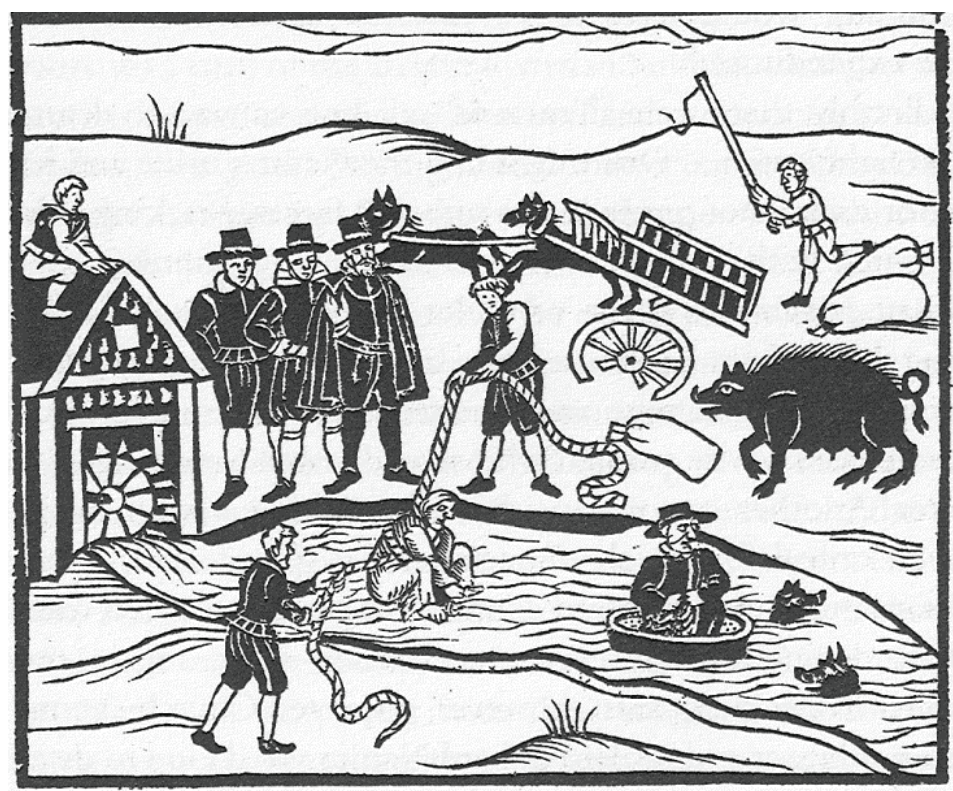

Źródło: M. Gaskill, Witchfinders. A seventeenth-century English tragedy, London 2005, s. 106.

\section{„Renesans” pławienia w XVI w.}

W przeciwieństwie do pozostałych ordaliów próba zimnej wody nadal funkcjonowała w XVI-XVIII w. i to wyłącznie w związku z procesami o czary. Stosowanie jej na początku XVI w. na Litwie potwierdził w poemacie o żubrze (1521/1522 r.) Mikołaj Hussowski, będący najprawdopodobniej świadkiem jednej z nich ${ }^{68}$. Około 1550 r. w Polsce, w Nieszawie - w tamtejszym kościele klasztornym Franciszkanów, pojmano z kolei kobietę oskarżoną o czary i pławiono ją w Wiśle. Nie wiemy jednak, jak próba ta przebiegła i jaki był jej efekt ${ }^{69}$.

68 M. Hussowski, Pieśń o żubrze, jego postaci, dzikości i o polowaniu na niego, Supraśl 2007, s. 64-65; por. M. Pilaszek, Procesy o czary w Polsce w wiekach XV-XVIII, Kraków 2008, s. 406.

69 J. Wijaczka, Próba zimnej wody (ptawienie)..., s. 78. 
„Renesans” próby zimnej wody na dobre rozpoczął się dopiero w drugiej połowie XVI w., kiedy ponownie zaczęła ona być przeprowadzana w trakcie coraz liczniejszych procesów o czary ${ }^{70}$. W krajach Rzeszy w latach 70. XVI w. pławienie zaczęło być stosowane na szerszą skalę $e^{71}$ - nie tylko w księstwach protestanckich, w których zakaz papieski z 1215 r. stał się nieważny, lecz także w katolickich, jak choćby w biskupstwie Münsteru ${ }^{72}$.

Pławienie domniemanych czarownic i czarowników w ostatnich dziesięcioleciach XVI w. wykorzystywano także w niektórych regionach Francji (Lotaryngia) ${ }^{73}$, w Skandynawii ${ }^{74}$ i w państwie polsko-litewskim ${ }^{75}$. Na przeprowadzanie próby zimnej wody w trakcie procesów o czary zgodził się władca księstwa Jülich-Cleve, wydając w tej sprawie odpowiedni mandat (24 lipca 1581 r.) ${ }^{76}$. Próba wody zaczęła być używana w latach 80 . XVI w. w Geldrii, dokąd dotarła z sąsiednich krajów niemieckich i stała się popularna w lokalnych sądach. Wykonywano ją m.in. w miejscowościach Harderwijk,

70 Por. P. Oestmann, Hexenprozesse am Reichskammergericht, Köln-Weimar-Wien 1997, s. 207, przypis 693; H. Pihlajamäki, op. cit., s. 35-58.

71 W. G. Soldan, H. Heppe, op. cit., Bd. 2, s. 82; G. Schormann, Hexenprozesse in Nordwestdeutschland, s. 118-124; P. A. Heuser, op. cit., s. 88. Trzeba jednak dodać, że w krajach Rzeszy bardziej popularna od próby zimnej wody w procesach o czary była ponoć próba igły; G. Schormann, Hexenprozesse in Deutschland, Göttingen 1981, s. 47-48.

72 S. Lorenz, Aktenversendung..., s. 454; S. Alfing, Hexenjagd und Zaubereiprozesse in Münster. Vom Umgang mit Sündenböcken in den Krisenzeiten des 16. und 17. Jahrhunderts, Münster-New York 1991, s. 95.

73 W. Rummel, R. Voltmer, op. cit., s. 47.

74 W Finnmark, jednej z prowincji państwa norweskiego, próbę wody przeprowadzono w 30 z 40 procesów, które odbyły się w całym królestwie norweskim; L. H. Willumsen, Witches of the North. Scotland and Finnmark, Leiden-Boston 2013, s. 268.

75 M. Madar, op. cit., s. 266. Autor ten podał informację, że w 1588 r. w Dorpacie (Tartu) - należącym wówczas do państwa polsko-litewskiego - próbie wody poddany został Marcin Gaijnowski. Rzucony na wodę utrzymywał się na jej powierzchni; V. M. Mokienko, U. Scholz, Die russische Hexe (ihre ikonographische Erscheinung, magische Handlungen, Lebensraum und Funktion), w: Hexenverfolgung in Mecklenburg. Regionale und überregionale Aspekte, Hrsg. D. Harmening, A. Rudolph, Dettelbach 1997, s. 237; A. Lavrov, A 1646 case of ,ordeal by water" of individuals accused of witchcraft in the Grand Dutch of Lithuania, „Russian History” 2013, vol. 40, no. 3-4, s. 508-517.

76 W. G. Soldan, H. Heppe, op. cit., Bd. 1, s. 497. 
Nijmegen, Bredevoort i Barneveld ${ }^{77}$. Pławienie zostało jednak odrzucone przez trybunał w Arnhem już w latach 90., ponieważ zasiadający w nim sędziowie uznali próbę tę za niewiarygodną ${ }^{78}$.

$\mathrm{Na}$ Węgrzech do pierwszych prób zimnej wody związanych z oskarżeniami o czary miało dojść w $1588 \mathrm{r}^{79} \mathrm{~W}$ hrabstwie Flandrii przeprowadzono pławienie jedynie $\mathrm{w}$ trakcie kilku procesów z 1595 r. Jeszcze w tym samym roku zabroniono jego stosowania ${ }^{80}$. Podobnie było w Szkocji, gdzie próba wody w procesach o czary była stosowana tylko w $1597 \mathrm{r}^{81}$

W 1593 r. w Schellinkhout, w jednym z miasteczek na północy ówczesnego hrabstwa Holandii, ławnicy tamtejszego sądu zdecydowali, aby pomówioną o czary kobietę poddać próbie wody. Odwołała się ona od tej decyzji do sądu apelacyjnego, którego sędziowie postanowili zwrócić się z pytaniem o dopuszczalność dowodów uzyskanych na podstawie pławienia do profesorów Wydziału Medycznego i Filozoficznego uniwersytetu w Lejdzie. Pisemną odpowiedź wystawiono 9 stycznia $1594 \mathrm{r}^{82}$, a stwierdzono w niej, że próba wody jest nieważna i nie ma mocy dowodowej. Na dodatek sposób wiązania kobiet „puszczanych” na wodę sprawiał, że ich ciała przyjmowały kształt małych stateczków, co ułatwiało utrzymywanie się na powierzchni wody ${ }^{83}$. Profesorowie, którzy przygotowali opinię, użyli w niej też argumentu medycznego - stwierdzając, że kobiety oskarżane o czary najczęściej są melancholiczkami. Ta choroba powoduje zaś, że cierpiące na nią kobiety są pulchne, przez co łatwiej utrzymują się na powierzchni wody niż zdrowe, czyli szczupłe ${ }^{84}$. Sąd apelacyjny uznał przesłaną mu argumen-

77 W. de Blécourt, Mangels Beweisen. Über das Ende der Verfolgung von Zauberinnen in Niederländischen und Spanisch Geldern 1590-1649, w: Das Ende der Hexenverfolgung, Hrsg. S. Lorenz. D. R. Bauer, G. Maier, Stuttgart 1995, s. 81.

78 Ibidem, s. 83.

79 P. Tóth, River ordeal..., s. 139-140.

80 J. Monballyu, Die Hexenprozesse in der Grafschaft Flandern (1495-1692). Chronologie, Soziographie, Geographie und Verfahren, w: Hexenprozesse und Gerichtspraxis, Hrsg. H. Eiden, R. Voltmer, Trier 2002, s. 294; W. Rummel, R. Voltmer, op. cit., s. 47.

${ }^{81}$ L. H. Willumsen, Witches of the North..., s. 267.

${ }^{82}$ W. G. Soldan, H. Heppe, op. cit., Bd. 1, s. 553.

83 Ibidem.

${ }^{84}$ H. de Waardt, Rechtssicherheit nach dem Zusammenbruch der zentralen Gewalt. Rechtspflege, Obrigkeit, Toleranz und wirtschaftliche Verhältnisse in Holland, w: Das Ende 
tację za przekonującą i zabronił ławnikom w Schellinkhout wykonywania próby wody ${ }^{85}$. Zakaz ten formalnie dotyczył jedynie dwóch prowincji Holandii i Zelandii, ale wkrótce został też wprowadzony w pozostałych niderlandzkich prowincjach ${ }^{86}$.

\section{Spory o stosowanie próby zimnej wody}

Stosowanie próby zimnej wody jako środka dowodowego w procesach o czary w końcu XVI w. miało licznych zwolenników, ale zaczęli się pojawiać i jej przeciwnicy. Arcybiskup-elektor Trewiru Johann von Schönenberg w 1591 r. wydał szczegółową ordynację w kwestii prowadzenia procesu o czary, w której przypominał, że próba zimnej wody jest prawnie niedozwolona $^{87}$. Większość radców katolickiego elektora Kolonii także zaczęła sprzeciwiać się wykorzystywaniu tej próby ${ }^{88}$. W sierpniu 1595 r. zareagowali na informację, że w okręgu Brühl została ona uznana za przesłankę do podjęcia tortur. Postanowili przywołać do porządku tamtejszy sąd. Nakazano mu podporządkować się przepisom ordynacji karnej Caroliny z 1532 r., która o niej nie wspominała ${ }^{89}$.

Być może postępowanie radców katolickiego elektora Kolonii wynikało z tego, że wraz z ponownym zastosowaniem próby zimnej wody w procesach o czary doszło do szerokiej dyskusji na temat zasadności jej używania ${ }^{90}$. Początek dyspucie dało opublikowanie, przez pracującego w Marburgu lekarza i filozofa Wilhelma Adolfa Scriboniusa (Schre-

der Hexenverfolgung, s. 133-134; idem, Witchcraft and wealth: the case of the Netherlands, w: The Oxford handbook of witchcraft in early modern Europe and colonial America, ed. B. P. Levack, Oxford 2013, s. 243.

${ }^{85}$ H. de Waardt, Witchcraft and wealth: the case of the Netherlands, s. 243.

${ }^{86}$ Ibidem.

87 E. Labouvie, Zauberei und Hexenwerk. Ländlicher Hexenglaube in der frühen Neuzeit, Frankfurt am Main 1991, s. 55.

${ }_{88}$ P. A. Heuser, op. cit., s. 85. Jednym z nich był dr Andreas Gaill (1526-1587), który w latach 1584-1587 pełnił funkcję kanclerza i radcy. Dał temu wyraz również w rozprawie wydanej drukiem w 1586 r. w Kolonii.

89 Ibidem, s. 85.

${ }_{90}$ Zob. m.in. P. A. Heuser, op. cit., s. 73-135. 
iber, ok. 1550-1600), pracy De examine et purgatione sagarum per aquam fridigam epistola (Frankfurt 1583) ${ }^{91}$, w której opowiedział się on za wiarygodnością tej próby. Scribonius napisał ten tekst na prośbę rady miejskiej Lemgo, która poprosiła go o opinię, ponieważ jej członkowie chcieli wiedzieć, czy próbę wody można stosować w procesach o czary jako dowód. Pragnęli też dowiedzieć się, czy próba ta ma uzasadnienie. Rada chciała też poznać odpowiedź na pytanie, dlaczego czarownice utrzymują się na powierzchni wody, a niewinne kobiety idą na dno. Trzeba dodać, że hrabstwo Lippe, w którym Lemgo leżało, było w czasach wczesnonowożytnych jednym z centrów polowania na czarownice w Rzeszy ${ }^{92}$.

Na pytanie: „Dlaczego czarownice utrzymują się na wodzie?”, Scribonius odpowiedział, że wewnętrzna forma ciała czarownicy zmienia się z chwilą zawarcia przez nią paktu z diabłem. Ma go ona bowiem odtąd w swoim ciele, a ponieważ diabeł jest lekkim, przewiewnym duchem, czarownica staje mu się w tym względzie podobna i sama robi się lekka. Dlatego też kobiety, które zawarły pakt z diabłem, utrzymują się na powierzchni wody ${ }^{93}$. Na podniesiony później zarzut, że próba wody nie może być wiarygodna, ponieważ szatan nie pozwoliłby na publiczne odkrycie swoich pomocnic, Scribonius odparł, że szatan nie pomaga w trakcie pławienia swoim pomocnicom z tego powodu, by pokazać władzy świeckiej i widzom obserwującym przeprowadzane próby wody, jak wiele osób stoi po jego stronie ${ }^{94}$.

Rada miejska Lemgo, niby dla pewności, zamówiła drugą opinię na temat próby zimnej wody. Napisał ją filozof, profesor logiki na uniwersytecie w Marburgu, Rudolph Goeckel (Rodolphus Goclenius). Goeckel opowiedział się przeciwko stosowaniu pławienia ${ }^{95}$. Jego opinię rada miejska jednak

91 G. Gersmann, Skizze einer Geschichte der Wasserprobe, s. 159.

92 Hexenverfolgung und Regionalgeschichte. Die Grafschaft Lippe im Vergleich, Hrsg. G. Wilbertz, G. Schwerthoff, J. Scheffler, Bielefeld 1994; Biographieforschung und Stadtgeschichte. Lemgo in der Spätphase der Hexenverfolgung, Hrsg. G. Wilbertz, J. Scheffler, Bielefeld 2000.

93 G. Gersmann, Skizze einer Geschichte der Wasserprobe, s. 160.

94 Ibidem.

95 Opinia została opublikowana w formie książkowej: Oratio de natura sagarum in purgatione examinatione per Frigidam aquis innatantium w Marburgu w 1590 r.; P. A. Heuser, op. cit., s. 97. 
odrzuciła i w trakcie procesów o czary prowadzonych w następnych latach w Lemgo próba wody była przeprowadzana, także na prośbę sądzonych osób $^{96}$. Działo się tak, mimo że w 1603 r. władca hrabstwa - Szymon VI, zabronił posługiwania się nią, uważając próbę wody za zabobonne działanie niemające mocy prawnej. Lemgo, stosując pławienie, broniło w ten sposób swojej sądowej autonomii ${ }^{97}$.

Tezy Wilhelma Adolfa Scriboniusa wywołały ożywioną dyskusję w świecie teologów, prawników i lekarzy. Jedynie nieliczni podzielali jego argumentację. Był wśród nich Jacob Rick z Ahrweiler, ławnik sądu najwyższego w Bonn, który w 1597 r. w Kolonii opublikował po łacinie 80-stronicową rozprawę zatytułowaną Defensio compediosa [...] probae [...] aquae frigidae, qua in examinatione maleficarum iudices hodie utuntur ${ }^{98}$. Rick argumentował, że sędzia powinien mieć swobodę i niezależność w wyborze sposobu procedowania, a władze świecka i kościelna nie powinny się do tego wtrącać. W ogóle Rick idealizował obraz sędziego, jako „dobrego męża”, który ponosi odpowiedzialność i ciężar wydania sprawiedliwego wyroku. Jego zdaniem sędzia powinien dbać o przebieg procesu, aby zachowane zostało „powszechne dobro" ${ }^{99}$. Rick dowodził także, że najczęściej próba wody ma pozytywny skutek m.in. z tego powodu, że oskarżeni, którzy w jej trakcie nie poszli pod wodę, szybciej składają zeznania ${ }^{100}$. To, że w prawie kanonicznym zawarty był zakaz stosowania próby zimnej wody, Rick postanowił ominąć - stwierdzając, że sekta czarownic pojawiła się dopiero niedawno, dlatego też stare kościelne kanony nie powinny dotyczyć wykorzystywania tej próby w obecnych procesach o czary ${ }^{101}$.

W wykształconym środowisku zdecydowana większość, przede wszystkim lekarzy i prawników, odrzucała próbę zimnej wody. Zanegowali ją głównie lekarze. Jako pierwszy polemikę ze Scriboniusem podjął

96 M. Ströhmer, Von Hexen, Ratsherren und Juristen. Die Rezeption der Peinlichen Halsgerichtsordnung Kaiser Karls $V$. in den frühen Hexenprozessen der Hansestadt Lemgo 1583-1621, Paderborn 2002, s. 213.

97 Ibidem, s. 209.

98 P. A. Heuser, op. cit., s. 71, argumentacja Ricka na s. 94-106.

99 Ibidem, s. 99-100.

100 Ibidem, s. 100.

101 Ibidem. 
Hermann Neuwalt (Neuwald) ${ }^{102}$, który wywodom kolegi po fachu nie szczędził ostrej krytyki, twierdząc, że poglądy przez niego głoszone nie tylko obrażają sprawiedliwość Boską, ale są też nieuczciwe i szkodliwe. Neuwalt odrzucał stosowanie próby wody jako postępowanie okrutne i zabobonne, choć nie kwestionował przestępstwa czarostwa. Nie wierzył natomiast $\mathrm{w}$ to, że po wejściu demona w ciało staje się ono w efekcie lżejsze ${ }^{103}$. Jego traktat był szeroko dyskutowany, a także zamieszczony w opublikowanym w 1586 r. przez prawnika Abrahama Saura zbiorze, zawierającym 17 traktatów poświęconych kwestii czarostwa. Zbiór ten zatytułowano Theatrum de Veneficis ${ }^{104}$. Trzeba dodać, że również traktat Scriboniusa został włączono do tego tomu.

Twierdzenie Wilhelma Adolfa Scriboniusa, że ciało kobiece zmienia się pod wpływem diabła, napotkało również gwałtowny sprzeciw innego lekarza - Johanna Ewicha, który odrzucił próbę wody jako „miłą bajkę”, ale jednak niebezpieczną i bezbożną ${ }^{105}$.

Próba zimnej wody została zakwestionowana nie tylko przez lekarzy, ale i prawników - m.in. przez profesora uniwersytetu w Rostocku, Johanna Georga Gödelmanna (1559-1611) ${ }^{106}$. Przeciwnikiem przeprowadzania

102 C. Kauertz, Neuwalt, Hermann, w: Lexikon zur Geschichte der Hexenverfolgung, Hrsg. G. Gersmann, K. Moeller, J.-M. Schmidt, https://www.historicum.net/purl/45zsj/ (dostęp: 1.08.2015); idem, Wissenschaft und Hexenglaube. Die Diskussion des Zauber-und Hexenwesens an der Universität Helmstedt (1576-1626), Bielefeld 2001, s. 166-168.

${ }_{103}$ H. Neuwalt, Exegesis Purgationis sive examinis sagarum super aquam frigidam proiectarum: In qua Refutata opinione Guilhelmi Adolphi Scribonii, de hujus purgationis \& aliarum similium origine, natura, \& veritate agitur: Omnibus ad rerum gubernacula sedentibus maxime necessaria, Helmstedt 1584; w tym samym mieście i roku ukazała się niemiecka wersja pracy Neuwalta; C. Kauertz, Neuwalt..., s. 1.

104 G. Scholz Williams, Demonologies, w: The Oxford handbook of witchcraft..., s. 77.

$105 \mathrm{~J}$. Ewich, De sagarum (quas vulgo veneficas appellant) natura, arte, viribus et factis: item de notis indicisque, quibus agnoscantur: et poena, qua afficiendae sint, Bremen 1584; niemiecka wersja ukazała sie rok później: J. Ewich, Von der Hexen, Die man gemeiniglich Zauberin nennet, oder auff niedersechsisch Töuerschen, Natur, Kunst, Macht und Thaaten, Item von den Merckzeichen da bey sie zu erkennen und straff, damit sie zu züchtigen Ein billich und rechtmessiges bedencken; Mit einverleibter erklerung, was von der wesentlichen verenderung und wasser prob der Hexen zu halten sey, Bremen 1585, s. 36-37.

106 J. G. Godelmanni, De magis, veneficis et lamiis, deque his recte cognoscendis et puniendis. Libri tres, Francoforti 1591; niemieckie tłumaczenie: J. G. Gödelmann, Von 
próby wody, a także tortur - czy w ogóle procesów o czary - był prawnik Justus Oldekop (1597-1667), który jako jeden z pierwszych odrzucił możliwość lotów czarownic i utrzymywania przez nie stosunków seksualnych z diabłem ${ }^{107}$.

Przeciwko stosowaniu i ważności próby zimnej wody opowiedzieli się również sędziowie Trybunału Rzeszy w jednym z wyroków ze stycznia 1598 r. ${ }^{108}$ Jednak dopiero kilkadziesiąt lat później, w 1665 r., Trybunał ten jednoznacznie opowiedział się przeciwko uznawaniu pławienia jako legalnego środka w pozyskiwaniu przesłanek procesowych i odtąd konsekwentnie się tego trzymał ${ }^{109}$. Podobnie zaczęły postępować wydziały prawa niemieckich uniwersytetów (przykładowo w Rostocku), do których zwracano się z prośbami o opinie w procesach o czary ${ }^{110}$.

Co ciekawe, próbę wody odrzucali też niektórzy z gorliwych zwolenników polowania na czarownice, jak choćby biskup trewirski Peter Binsfeld ${ }^{111}$ czy też jezuicki teolog, teoretyk czarostwa Martin Delrio (Del Rio) ${ }^{112}$, uznając ją za niewiarygodną.

Negacja próby wody przez uczonych i instytucje prawne, a także niektórych teologów nie miała jednak wpływu na jej popularność w społeczeństwie niemieckim. Tylko w Westfalii, jednym z centrów pławienia w czasach wczesnonowożytnych, przeprowadzono kilkaset prób wody, w tym liczne

Zäuberern Hexen und Unholden, warhafftiger und wolgegründter Bericht Herrn Georgii Gödelmanni..., wie dieselbigen zuerkennen und zu straffen, Francoforti 1592; S. Lorenz, Johann Georg Godelmann - ein Gegner des Hexenwahns?, w: Beiträge zur mecklenburgischen und pommerschen Geschichte, Hrsg. R. Schmidt, Marburg 1981, s. 61-105, tu: s. 81-82.

${ }_{107}$ H. Presgebauer, Zur Geschichte von Sexualität, Körper und Gender in der europäischen Hexenverfolgung, Wien 2009, s. 120.

108 P. Oestmann, Hexenprozesse am Reichskammergericht, s. 210; idem, Die Rechtsprechung des Reichskammergerichts zum Hexenprozeß und ihre Resonanz, w: Hexenprozesse und Gerichtspraxis, Hrsg. H. Eiden, R. Voltmer, Trier 2002, s. 437.

109 P. Oestmann, Hexenprozesse am Reichskammergericht, s. 212.

110 R. Zagolla, Folter und Hexenprozess. Die strafrechtliche Spruchpraxis der Juristenfakultät Rostock im 17. Jahrhundert, Bielefeld 2007, s. 283-285.

111 G. Gersmann, Skizze einer Geschichte der Wasserprobe, s. 161.

112 P. A. Heuser, op. cit., s. 107 i nast.; J. Sharpe, The demonologists, w: The Oxford illustrated history..., s. 83. 
na wniosek samych oskarżonych ${ }^{113}$. Na stosowanie pławienia wpływało bez wątpienia to, iż mimo że Kościół katolicki w 1215 r. zabronił udziału duchownych $\mathrm{w}$ przeprowadzaniu tej próby, to w czasach wczesnonowożytnych liczni duchowni (w tym także kościelni hierarchowie) lekceważyli ten zakaz. Tak było chociażby w katolickim biskupstwie Münsteru, gdzie biskupi osobiście byli zaangażowani w procesy o czary i przez długie dziesięciolecia akceptowali pławienie oskarżonych kobiet ${ }^{114}$. Nie było to jednak reguła, w katolickim arcybiskupstwie Moguncji próba wody w XVII w. bowiem właściwie nie była stosowana ${ }^{115}$.

Jedni biskupi katoliccy akceptowali pławienie, inni go zakazywali. Johann Friedrich, arcybiskup Bremy, wydał w 1603 r. edykt, w którym stwierdzał, że próba wody ma więcej związku z pogańskimi niż chrześcijańskimi zwyczajami, i dlatego jej zakazał ${ }^{116}$. Do akceptujących próbę wody należał m.in. katolicki biskup wileński Michał Jan Zienkiewicz, który w trakcie zwołanego przez siebie synodu, obradującego w dniach 10-13 lutego 1744 r. w Wilnie, doprowadził do podjęcia uchwały zabraniającej pławienia kobiet podejrzewanych o czary bez zgody biskupa ${ }^{117}$. Zalecał, aby przestrzegania zakazu dopilnowali w diecezji duchowni. Mieli oni za zadanie nie pozwalać sądom świeckim więzić i pławić podejrzanych o czary bez wcześniejszego śledztwa przeprowadzonego przez duchownego ${ }^{118}$. Aprobował więc stosowanie tej próby, ale chciał mieć możliwość decydowania, w którym przypadku ma być przeprowadzona.

Trzeba jednak zauważyć, że przeciwników próby wody stopniowo przybywało także wśród niższych duchownych, przede wszystkim luterańskich. W czerwcu 1639 r. próba wody stała się tematem kazań wygłaszanych w Osnabrücku przez dwóch tamtejszych luterańskich kaznodziejów

113 G. Gersmann, Skizze einer Geschichte der Wasserprobe, s. 162.

114 Idem, Wasserproben und Hexenprozesse..., s. 469-480.

115 H. Gebhard, Hexenprozesse im Kurfürstentum Mainz des 17. Jahrhunderts, Aschaffenburg 1989, s. 133.

116 G. Schormann, Hexenprozesse in Nordwestdeutschland, s. 119.

117 J. Kurczewski, Kościót zamkowy, czyli Katedra wileńska w jej dziejowym, liturgicznym, architektonicznym i ekonomicznym rozwoju. Na podstawie aktów kapitulnych i dokumentów historycznych, Wilno 1908, s. 187.

118 Ibidem, s. 208. 
z kościoła św. Marii. Obaj zdecydowanie występowali przeciw jej przeprowadzaniu $^{119}$. Sprzeciwiali się także dalszemu inicjowaniu procesów o czary. Jeden z nich, pastor Gerhard Grave, napisał również pracę poświęconą pławieniu, którą opublikował rok później, Abgenötigte Rettung und Erklärung, zweyer zu Rinteln, jüngsthin, gedruckter Send-Brieffe, so mit Arrest sind hieselbst befangen: in welchen wird gehandelt von der Wasser-Prob oder vermeintem Hexenbaden (Rinteln 1640) ${ }^{120}$, przyczyniając się w ten sposób w znacznej mierze do zakończenia procesów w Osnabrücku.

\section{Pouszechność wiary w uiarygodność próby zimnej wody (pławienie „na życzenie”)}

Wiara $\mathrm{w}$ niezawodność próby wody była w XVI-XVIII w. powszechna w prawie wszystkich europejskich społeczeństwach. W efekcie osoby oskarżane o uprawianie czarów - zarówno kobiety, jak i mężczyźni - często prosiły, aby poddano je tej próbie, będąc pewnymi, że w ten sposób oczyszczą się z zarzutu ${ }^{121}$. Latem 1608 r. o przeprowadzenie próby wody, która dowiodłaby jej niewinności, poprosiła Hille Blomers z Marbeck - położonego w szlacheckiej enklawie Lembeck ${ }^{122}$. W okręgu Bocholt w Westmünsterland w 1611 r. tak wielu ludzi domagało się zastosowania próby wody, że tamtejszy starosta zwrócił się do przełożonych w Münsterze z prośbą, aby mu powiedziano, co ma w takiej sytuacji uczynić ${ }^{123}$. Trine Eggersen, sądzona w 1626 r., była przekonana, że każdy chrześcijanin idzie pod wodę

119 H. J. Stebel, op. cit., s. 46.

120 Ibidem, s. 47; K. Moeller, Grave, Gerhard, w: Lexikon zur Geschichte...

121 R. Zagolla, op. cit., s. 285; G. Gersmann, Wasserproben und Hexenprozesse..., s. 449-480. Ponieważ korzystałem z wersji zamieszonej w Internecie: www.members. tripod.de/hexforum/daten/wass.rtf, to cytuję według podanych tam stron, tu: s. 30-31; Ch. Gerst, Hexenverfolgung als juristischer Prozess. Das Fürstentum Braunschweig-Wolfenbüttel im 17. Jahrhundert, Göttingen 2012, s. 216.

122 G. Gersmann, Von schwemmern und sinkern. Hexenverfolgungen und Wasserproben in der münsterländischen Herrlichkeit Lembeck, w: Alltagsleben und Magie in Hexenprozessen, s. 95.

123 M. Saatkamp, Von den bösen Weibern die man nennet die Hexen. Quellen und Ausstellungstexte, Borken 1992, s. 27. 
w trakcie próby pławienia, i miała nadzieję, że z nią będzie podobnie. W przypadku, gdyby tak się jednak nie stało, to wówczas sąd będzie mógł uczynić z nią, co tylko zechce ${ }^{124}$. W 1638 r. pewien chłop w Burgundii kazał się pławić dwukrotnie, aby dowieść swej niewinności ${ }^{125}$. O poddanie próbie zimnej wody prosił sąd z Kowalewa (Pomorskiego) w 1648 r. mąż Anny Maruny, uważając, że oczyści ona jego żonę z zarzutu czarostwa. Sąd początkowo nie zgodził na przeprowadzenie pławienia, ale za ponowną prośbą oskarżona została pławiona przez kata i próba wypadła dla niej niekorzystnie. Załamana, poddana po raz trzeci torturom, przyznała się do utrzymywania kontaktów z diabłem ${ }^{126}$.

O próbę wody prosiła też oskarżona o uprawianie czarów w hrabstwie Lippe w 1663 r. stara Hasinowa, która nie tylko nalegała na poddanie jej pławieniu, lecz także zobowiązywała się do pokrycia kosztów jej ewentualnego procesu, gdyby ono nie oczyściło jej z zarzutu. Nie odstąpiła od tego zamiaru nawet po ostrzeżeniach zięcia, który przekonywał ją, że próba wody jest zwodnicza ${ }^{127}$.

W maju 1665 r. w amcie Rotenburg (Saksonia) o przeprowadzenie próby wody prosiły trzy oskarżone o czary kobiety, a także ich mężowie, córki i synowie. Na pytanie sądu, czy w przypadku, gdy będą utrzymywały się na powierzchni wody, przyznają, że są czarownicami, jednogłośnie udzieliły twierdzącej odpowiedzi. Sąd zgodził się wówczas na przeprowadzenie pławienia. Oskarżone, a także członkowie ich rodzin, prosili, aby kobiety mogły same udać się do stawu koło młyna, a nie być tam doprowadzone przez pachołków katowskich, gdyż jeszcze nie udowodniono im winy, w związku z czym czuły się niewinne. Ich prośba została zaakceptowana. Gdy znalazły się nad stawem, rozebrały się. Dopiero wówczas kat i jego pomocnicy wsadzili je do łódki, z której trzykrotnie wrzucali je do wody. Wszystkie trzy pływały na wodzie ,jak gęsi”, co miało jednoznacznie świadczyć o tym, że były czarownicami. Diederich Haßstedte, mąż jednej

124 R. Schulte, op. cit., s. 53.

125 R. Bartlett, op. cit., s. 150.

126 J. Wijaczka, Procesy o czary przed sądem sottysim Kowalewa (Pomorskiego) w XVII-XVIII wieku, „Zapiski Historyczne” 2017, t. 82, z. 2, s. 106-107.

127 R. Walz, Hexenglaube und magische Kommunikation im Dorf der frühen Neuzeit. Die Verfolgungen in der Grafschaft Lippe, Paderborn 1993, s. 356. 
z pławionych kobiet, poprosił sędziego, aby pozwolono kupić mu nowy sznur i ponownie przeprowadzić próbę jego żony. Tak się stało, ale kobieta nadal utrzymywała się na powierzchni wody ${ }^{128}$. Postawione przed obliczem sądu kobiety, mimo wcześniej złożonej obietnicy, nie chciały się jednak przyznać do bycia czarownicami - twierdząc, że z nieznanych powodów Bóg jednak nie dał im pójść pod wodę. Nie wiemy, jak proces ostatecznie się zakończył dla dwóch kobiet Anny Ratken i Tibke Berendts (Hollmann), natomiast trzecia z nich, Anna Haßstedte spłonęła na stosie ${ }^{129}$.

W 1690 r. o przeprowadzenie próby wody prosiło z kolei pięć osób powołanych w procesie, który toczył się przed sądem z Łobżenicy (Wielkopolska). W ten sposób pragnęły oczyścić się z zarzucanego im czarostwa. Nie powiodło się to, ponieważ „na który wodzie pomienioni wszyscy powołani jednak na wierzchu pływali. Spytani czemu znać się [inaczej] pokazuje niżeli sobie obiecali, to jest tonąć mieli, a oni pływali, powiadali, że mistrz powróz nie popuszczał i onych zatrzymywał i drągiem podnosił w wodzie" ${ }^{130}$. Podobne przykłady proszenia oskarżonych o przeprowadzenie próby wody w procesach o czary, które toczyły się w XVII w., można mnożyć131.

Naleganie osób oskarżonych o przestępstwo czarostwa, aby poddano je próbie wody, wynikało nie tylko z wiary, że woda „oczyści” je z zarzutu, i dzięki temu uwolnią się od trudnej sytuacji, w jakiej znalazły się z powodu oskarżenia. Oskarżenie o czary stawiało je bowiem na marginesie życia danej lokalnej społeczności. Często jedynym wyjściem z takiej izolacji było właśnie poddanie się pławieniu ${ }^{132}$. Potwierdzają to badania m.in. Rainera

128 Wasserprobe der Hexen im XVII. Jahrhundert, „Journal von und für Deutschland” 1785, Jg. 2, H. 7-12, s. 548; Protokoll einer Wasserprobe in Rotenburg/Wümme, w: J. Wookke, Unterrichtsmaterialien zum Thema „Hexenverfolgung im Stift Verden und in den Herzogtümern Bremen-Verden“, Verden 2009, s. 63, http://www.regionalgeschichte-verden.de/ Dateien/Hexen/Unterrichtsmaterialien_Hexenverfolgung.pdf (dostęp: 21.12.2017).

129 Wyrok zapadł 24 lipca 1665 r.; Wasserprobe der Hexen..., s. 549; J. Hoops von Scheeßel, H. Ringe von Bertelsdorf, Mißbraucht \& verbrannt. Die Hexenprozesse im Amt Rotenburg, Bistum Verden, Stuttgart 2009, s. 245.

130 Archiwum Państwowe w Bydgoszczy, Akta miasta Łobżenicy (AmE), sygn. 11, k. 533 r.

131 Dochodziło do nich choćby w księstwach Szlezwiku i Holsztynu oraz w Meklemburgii; R. Schulte, op. cit., s. 53; S. Lorenz, Aktenversendung..., s. 452.

${ }_{132}$ G. Gersmann, Wasserproben und Hexenprozesse..., s. 31. 
Walza, który stwierdził wyraźnie, że to, iż tak wiele kobiet w hrabstwie Lippe prosiło o poddanie ich próbie pławienia, nie wynikało tylko z utrzymujących się na wsi przesądów, lecz właśnie było często jedynym wyjściem z sytuacji. Przesąd związany z próbą zimnej wody utrzymywał się tak długo, ponieważ w ramach ówczesnego wiejskiego systemu prawa nie było pławienia czym zastąpić1 ${ }^{133}$.

Próba wody była jednak zagrożeniem obosiecznym, a prośba o jej przeprowadzenie mogła potwierdzić w oczach sąsiadów, że dotychczasowa „zła sława”, mówiąca, że dana kobieta/mężczyzna jest czarownicą/czarownikiem, mogła zostać w ten sposób potwierdzona ${ }^{134}$. Dlatego też niektóre z oskarżanych osób odmawiały poddania się próbie wody, także w sytuacji, gdy oskarżyciel również chciał się poddać próbie, a pławienie przybierało wówczas postać pojedynku. Takiego pojedynku odmówiła w 1654 r. Ilsche Huxhols, kiedy to bycie czarownicą zarzucił jej Hermann Klemme, a jej sąsiad Heinrich Herzog wezwał ją, aby poddała się pławieniu. Wtedy to Klemme zaoferował, że wraz z nią przystąpi do takiej próby. Huxhols odmówiła, stwierdzając, że ona jest szczupła, natomiast jej „konkurent” do próby to ciężki mężczyzna, w związku z czym on z pewnością pójdzie pod wodę, a ona się utrzyma na jej powierzchni. Do pojedynku wówczas nie doszło, ale 10 lat później Herzog zarzucił sąsiadce czarostwo, twierdząc, że za pomocą czarów sprowadziła na niego chorobę. Oskarżona odparła, że w tej sytuacji także Herzog i jego żona powinni zostać poddani pławieniu. Sąsiad odparował, że w takim razie i syn Huxhols niech podda się próbie ${ }^{135}$. Tym razem także do pławienia nie doszło.

Niektóre kobiety w hrabstwie Lippe odmawiały poddania się próbie pławienia, wierząc, że mogą się utrzymywać na powierzchni wody z powodu popełnienia innych grzechów, w tym zdrady małżeńskiej ${ }^{136}$.

133 R. Walz, op. cit., s. 358.

134 W Münsterze w końcu XVI w. prośba o przeprowadzenie próby wody zgłaszana przez oskarżaną osobę była traktowana jako dowód obciążający i nie przeprowadzano jej, tym bardziej że wśród członków rady miejskiej zadomowił się pogląd, że pławienie jest oszustwem diabła, gdyż każde ciało w naturalny sposób idzie pod wodę; S. Alfing, op. cit., s. 95-96.

135 R. Walz, op. cit., s. 360.

136 Ibidem, s. 362. 
W funkcjonowaniu próby zimnej wody w XVI-XVIII w. istotny był również nacisk „od dołu”, czyli powszechna wśród społeczeństwa europejskiego wiara w oczyszczenie się z zarzutu czarostwa, ponieważ Bóg, a także poświęcona woda, nie pozwoli skrzywdzić niewinnej osoby. Stąd też zapewne niejednokrotnie na sędziach czy urzędnikach odpowiedzialnych za przestrzeganie prawa „wymuszano” przeprowadzenie próby, nawet jeśli nie byli do niej przekonani. Tak postąpił m.in. Jacob Vockin, wójt w miejscowości Winterswijk (obecnie wschodnia Holandia), który w 1611 i 1612 r. wysyłał podejrzane o czary osoby do Lembeck, aby tam poddały się próbie wody i wróciły z odpowiednim zaświadczeniem ${ }^{137}$. Dzięki temu powszechnemu przekonaniu szlacheckie sądy w Lembeck, Mefreld i Ostendorf zaczęły na szeroką skalę przeprowadzać próby pławienia, za które im płacono, a one w zamian wystawiały certyfikat niewinności. Następnie dana osoba wracała do rodzinnej miejscowości, gdzie była podejrzewana o uprawianie czarów, aby - na podstawie certyfikatu - dowieść swojej niewinności ${ }^{138}$.

Przeprowadzenie próby wody wymógł też na swym władcy Heinrich Schnökel ze wsi Herzebrock we władztwie Rheda (Westfalia) w 1668 r. Mimo że został wcześniej oczyszczony z zarzutu czarostwa, to w ten sposób chciał ostatecznie udowodnić sąsiadom, że zarzuty wobec niego były bezpodstawne ${ }^{139}$.

$\mathrm{Na}$ poddanie próbie wody osób pomawianych o czarostwo czasami nalegali też mieszkańcy wsi, w której taka osoby mieszkała, aby sprawdzić, czy zarzut jest prawdziwy. Tak stało się m.in. w 1665 r., kiedy na pewną kobietę ze wsi Kirchbraak (ówczesne księstwo Braaunschweig-Wolfenbüttel) padło w podejrzenie, że to ona sprawiła, że sąsiedzi doznali we wsi znacznych strat w bydle, a na dodatek ,zaczarowała” masło, które nie chciało się robić. Wszyscy mieszkańcy zwrócili się z prośbą do księcia Augusta

137 M. Saatkamp, Die Geschichte der Hexenverfolgungen, dargestellt an Beispielen aus dem Münsterland, w: Van Hexen un Düvelslüden. Über Hexen, Zauberei und Aberglauben im niederländisch-deutschen Grenzraum, Hrsg. M. Saatkamp, D. Schlüter, Entschede-Doetinchem-Vreden 1995, s. 24.

138 Adlige Lebenswelten im Rheinland. Kommentierte Quellen der Frühen Neuzeit, Hrsg. G. Gersmann, H.-W. Langbrandtner, Unter Miarb. M. Gussone, Köln-Weimar-Wien 2009, s. 312.

139 G. Schormann, Hexenprozesse in Nordwestdeutschland, s. 120. 
(1635-1666), aby kobietę poddać próbie wody, co w efekcie doprowadzi do uspokojenia sytuacji we wsi. Ponieważ książę już kilkanaście lat wcześniej nakazywał swoim radcom, aby próbę zimnej wody stosować ${ }^{140}$, to zapewne i w tym przypadku przystał na prośbę swych poddanych.

W wyjątkowych sytuacjach zdarzało się, że mimo utrzymywania się oskarżonej osoby na powierzchni wody nie dochodziło do dalszego postępowania sądowego, ponieważ oskarżyciele nagle wystraszyli się konsekwencji swego pomówienia. Przykładem może tu być wydarzenie, do którego doszło 28 kwietnia 1692 r. w ekonomii szawelskiej na Litwie. Mieszkańcy kilku okolicznych wsi skarżyli się na dwie kobiety ze wsi Mażele. Miały one rzekomo wyrządzić oskarżającym „wiele szkód w domach”. Przewodniczący sądu kazał katu przeprowadzić próbę pławienia. Próby dokonano w obecności licznych gapiów, a kobiety utrzymywały się na powierzchni wody. Po jej zakończeniu nikt nie chciał jednak podtrzymać oskarżenia i złożyć przysięgi, że kobiety są czarownicami, co skończyłoby się dla nich śmiercią. Prawdopodobnie oskarżyciele, znający przecież osobiście oskarżone kobiety i ich rodziny, wystraszyli się konsekwencji postawionych zarzutów. W tej sytuacji sąd postanowił uwolnić kobiety „od spalenia i w domach swoich na pokajanie od niebożnych postępków mieszkać [...], ex jednak cautione, jeżeliby in futurum jakowe się excessa czarodziejskie po nich pokazały, et pravevia documento dowiedzione były, tedy jako już powołane i już na wodzie próbowane ex nunc mają być spalone, aby takowa złość ludzka nie mnożyła się" 141.

Oczywiście wiara w to, że próba wody oczyści od zarzutu czarostwa, była fałszywa. Znam tylko jeden przypadek, w którym prośba o przeprowadzenie próby wody przez oskarżaną kobietę przyniosła jej uwolnienie od tego zarzutu. Chodzi o Katarzynę z domu Havemann, żonę Christiana Bätkego, mieszkającą we wsi Myśligoszcz (Marienfelde) w powiecie człuchowskim. Kobieta zmarła w końcu 1734 r., a kilka lub kilkanaście lat wcześniej (dokładna data nie jest znana) została oskarżona o związki z diabłem, czego powodem miała być zazdrość o powodzenie w hodowli bydła. Kobieta

140 A. Rahmm, Hexenglaube und Hexenprocesse vornämlich in den brandenburgischen Landen, Wolfenbüttel 1882, s. 26-27.

141 L. A. Jucewicz, Wspomnienie Żmudzi, Wilno 1842, s. 185-186. 
poprosiła właściciela wsi o przeprowadzenie próby wody, która miała dowieść jej niewinności. Właściciel uznał, że skoro poprosiła o pławienie, to musi być niewinna, ponieważ gdyby była czarownica, nie zaproponowałaby próby $^{142}$. Dlatego uwolnił ją od zarzutu.

$\mathrm{Na}$ przeprowadzanie próby wody często nalegali także, z różnych powodów, szlacheccy właściciele wsi i miasteczek, nawet jeśli urzędy centralne w danym księstwie były temu przeciwne. Przykładem szlachecka enklawa Lembeck w katolickim biskupstwie Münsteru, należąca w pierwszej połowie XVII w. do Mathiasa von Westerholta (1556-1618) i jego syna Bernharda (ca. 1590-1646). W latach 1610-1614 stosowanie próby zimnej wody osiągnęło tam apogeum. Do miasteczka ciągnęli z bliższej i dalszej okolicy ludzie oskarżani o czary w miejscowościach, w których na co dzień mieszkali, aby poddać się próbie wody. Takie osoby, uzyskawszy atestat niewinności, pragnęły powrócić i móc nadal spokojnie żyć w dotychczasowym środowisku. Tak uczyniła choćby - zamieszkała w okolicach Velen - żona Heinricha Schurena, która 22 sierpnia 1614 r. pozwoliła się pławić w Lembeck, aby udowodnić sąsiadowi, że nie jest czarownicą ${ }^{143}$. Do Lembeck przysyłali swoich poddanych, oskarżanych przez sąsiadów o bycie czarownicą lub czarownikiem, także szlacheccy właściciele dóbr, prosząc o poddanie ich próbie wody.

Zadłużeni właściciele Lembeck uczynili sobie z przeprowadzania próby wody dodatkowe źródło dochodu, od każdego pławionego pobierali bowiem 15 talarów, co w 1612 r. dało całkiem niezły dodatkowy dochód, ponieważ pławiono wówczas w miasteczku 52 osoby ${ }^{144}$. Próba zimnej wody nie tylko przynosiła więc właścicielowi miasteczka pieniądze, ale pozwalała również dodatkowo demonstrować sądową niezależność wobec władcy krajowego, coraz silniej dążącego do centralizacji władzy. Wskazując, że próba ta stanowi część „starego dobrego prawa” i w związku z tym może być stosowana, opierali się upomnieniom radców krajowych, którzy twierdzili, iż jest nielegalna. Ostatecznie jeden z biskupów diecezji Münster - Chri-

142 A. Treichel, Ein Beitrag zur Hexen-Geschichte Westpreußens, „Zeitschrift des historischen Vereins für den Reg. = Bezirk Marienwerder” 1882, H. 5, s. 238-239.

143 G. Gersmann, Wasserproben und Hexenprozesse..., s. 34.

144 Ibidem, s. 33. 
stoph Bernhard von Galen (bp 1650-1678) wydał w lipcu 1658 r. mandat, w którym zagroził ogromną karą finansową, w wysokości 2000 złotych guldenów, osobom w dalszym ciągu wykorzystującym próbę zimnej wody ${ }^{145}$. Dopiero wówczas zakończono praktyki pławienia.

Trzeba zaznaczyć, że sądy nie zawsze zgadzały się na przeprowadzenie próby wody na prośbę oskarżonych osób. Odmówił sąd w Gerresheim w 1737/1738 r., kiedy to poprosiła o nią jedna z oskarżonych kobiet, Agnes Olmans ${ }^{146}$. Aczkolwiek sądy lub rady miejskie zarządzały przeprowadzenie próby wody nawet wtedy, gdy protestowali obrońcy oskarżonych osób twierdząc, że z prawnego punktu widzenia pławienie nie jest dozwolone. Tak było m.in. w przypadku Anny Arents w 1642 r. w Glückstadt. Rada odparła, że w sąsiedniej Danii próba wody jest dozwolona, a w prawie karnym Rzeszy wyraźnie jej nie zabroniono ${ }^{147}$.

Nawet jeśli pod naciskiem sąd zgodził się na przeprowadzenie próby wody, to nie brał jej wyniku pod uwagę. Tak było w przypadku pławienia Triny Kefferbaum ze wsi Fürstenberg, które wykonano 20 lipca 1658 r. Próba wody odbyła się na prośbę oskarżonej. Choć sąd nie chciał się początkowo na nią zgodzić, w końcu uległ. Pławienie przeprowadzono trzykrotnie, a w jego trakcie obecni byli ławnicy i woźny sądowy. Podczas pierwszej próby związana i puszczona na wodę kobieta próbowała pójść pod wodę, zanurzając głowę, ale tylna część ciała pozostała na powierzchni. Nie pomogło nawet to, że kat za pomocą tyczki starał się jej w tym pomóc. Przy drugiej i trzeciej próbie kobieta nie była już związana, ale utrzymywała się na powierzchni. Ponadto Kefferbaum twierdziła nadal, że jest niewinna. Została uwolniona, ponieważ sąd uznał, że brakuje dowodów winy przede wszystkim przyznania się oskarżonej, ale mimo to została na rok wypędzona z miejscowości, w której mieszkała ${ }^{148}$.

145 Ibidem, s. 30.

146 E. Münster-Schröer, Verurteilt und verbrannt: Helena Curtens und Agnes Olmans. Der Gerresheimer Hexenprozess von 1737/1738. Mit vier Abbildungen, w: Hexenverfolgung. Vier Vorträge zur Erinnerung an Helena Curtens und Agnes Olmans aus Gerresheim, Hrsg. B. Mauer, Essen 2014, s. 33.

147 R. Schulte, op. cit., s. 52.

148 R. Decker, Die Hexen und ihre Henker. Ein Fallbericht, Freiburg im Breisgau 1994, s. 157. 


\section{Zakazy przeprowadzania próby wody}

Próba wody w związku z oskarżeniami o czary była stosowana zarówno w krajach katolickich, jak i protestanckich. W protestanckiej Anglii wierzono, że używana w trakcie chrztu woda odrzuci każdego, kto chrztu się wyparł i związał z diabłem. Próbę zimnej wody w trakcie procesu o czary przeprowadzano w Anglii od lat 90. XVI w. ${ }^{149}$, ale częściej sięgano do niej po 1610 r. ${ }^{150}$ Wykorzystywano tam próbę wody m.in. dzięki aprobacie wyrażonej dla niej przez wierzącego w czary króla Jakuba I (1603-1625) autora pracy Daemonologie, skierowanej przeciwko czarownicom (wydanej w 1597 r. $)^{151}$, w której stwierdził m.in., że: „Okazuje się, że Bóg nadprzyrodzony znak obrzydliwej bezbożności czarowników i czarownic wyznaczył to, że woda odmawia przyjęcia ich na swoje łono, wskazując, że strząsnęli z siebie świętą wodę chrztu i świadomie odrzucili wynikające z niej dobrodziejstwa" ${ }^{152}$. Po pewnym czasie król Jakub I zmienił zdanie. W latach 20. XVII w. nakłaniał sędziów, aby podzielili jego sceptycyzm w tej kwestii i przy sądzeniu osób oskarżanych o czary kierowali się wyłącznie prawnie uznanymi dowodami ${ }^{153}$. Mimo zmiany poglądów przez króla niektórzy $\mathrm{z}$ angielskich sędziów nadal nakazywali pławić oskarżone kobiety ${ }^{154}$.

Apogeum użycia próby zimnej wody w Anglii przypadło prawdopodobnie na okres działalności samozwańczego „generalnego tropiciela

149 K. Thomas, Religion and the decline of magic. Studies in popular beliefs in sixteenth and seventeenth century England, London 1971, s. 551.

150 H. Pihlajamäki, op. cit., s. 42; M. Gibson, Early modern witches. Witchraft cases in contemporary writing, London-New York 2000, s. 158, 167, 267, 274-276. James Sharpe stwierdził, że pierwsze źródłowe informacje o przeprowadzeniu próby wody w Anglii pochodzą z 1612 r.; J. Sharpe, Instrument of darkness. Witchcraft in England 1550-1750, London 1996, s. 218.

151 Zob. m.in. J. Sharpe, Instruments of darkness..., London 1996, s. 47-50.

152 Cyt. za: R. H. Robbins, Encyklopedia czarów i demonologii, tłum. M. Urbański, Warszawa 1998, s. 248.

153 M. Gaskill, Witchfinders. A seventeenth-century English tragedy, London 2005, s. $106-107$.

154 Idem, Witchcraft and evidence in early modern England, „Past and Present” 2008, vol. 198, s. 53. 
czarownic" Matthew Hopkinsa (ok. 1620-1647) i jego pomocnika Johna Stearnea (ok. 1610-1670). Działając w latach 1645-1647, przeprowadzili w kilku hrabstwach liczne pławienia - przede wszystkim kobiet. W niektórych miejscowościach władze lokalne sprzeciwiały się jednak tej próbie, więc przerzucili się na próbę igły ${ }^{155}$. Wśród pławionych (i torturowanych) znalazł się wówczas John Lowes, wikary w Brandenston (hrabstwo Suffolk) ${ }^{156}$. Pławiono go wraz z innymi osobami, które o nic nie oskarżano, a które, jak i on, utrzymywały się na powierzchni wody ${ }^{157}$. Przyznał się m.in. do zatopienia statku - ostatecznie został powieszony wraz z innymi oskarżonymi w Bury St Edmunds 27 sierpnia 1645 r. ${ }^{158}$ Dowiedziawszy się o poddaniu Lowesa próbie wody, parlament wysłał specjalną komisję, która miała powstrzymać tę praktykę ${ }^{159}$. Hopkins w traktacie The discovery of witches twierdził wprawdzie, że nie dopuszczał się próby wody jako dowodu w trakcie procesu. Zaznaczył jednak, że już król Jakub I zezwolił na kierowanie się jej rezultatem ${ }^{160}$.

Mimo wielu wątpliwości próba ta nadal funkcjonowała obok oficjalnego postępowania sądowego, wbrew protestom prawników i kleru ${ }^{161}$. Według Juliana Goodare’a pławienie w Anglii było stosowane jako nieformalna procedura przed rozpoczęciem procesu, która mogła, ale nie musiała, być brana pod uwagę przez sąd ${ }^{162}$. Malcom Gaskill uważał, że w ostatnich dzie-

155 K. Baschwitz, Czarownice. Dzieje procesów o czary, tłum. T. Zabłudowski, Warszawa 1999 , s. 169.

156 J. Sharpe, Instrument of darkness..., London 1997, s. 132.

157 R. Briggs, Die Hexenmacher. Geschichte der Hexenverfolgung in Europa und der Neuen Welt, übers. D. Muelder, Berlin 1998, s. 68.

158 G. Geis, I. Bunn, A trial of witches. A seventeenth-century witchcraft prosecution, London-New York 1997, s. 45.

159 S. M. Lundquist, Finding the witch's mark: female participation in the judicial system during the Hopkins trials 1645-1647 (2014), Departmental Honors Projects. Paper 18, s. 14, http://digitalcommons.hamline.edu/dhp (dostęp: 20.05.2018).

160 V. Perlhefter, Die Gestalt des „Hexenjägers“ des 17. Jahrhunderts und sein gesellschaftliches und politisches Umfeld. Adam Lebaldt von Lebenwaldt, Matthew Hopkins und Cotton Mather. Leben, Werke, Werdegänge, Frankfurt am Main 2003, s. 158.

161 O. A. Darr, Marks of an absolute witch. Evidentiary dilemmas in early modern England, Farnham 2011, s. 45, 163.

162 J. Goodare, The European witch-hunt, London-New York 2016, s. 200. 
sięcioleciach XVII w., kiedy angielski aparat sprawiedliwości stał się dosyć powszechnie niechętny dalszemu polowaniu na czarownice, prywatne osoby uznały próbę zimnej wody za alternatywne rozwiązanie ${ }^{163}$. To zapewne sprawiło, że próba wody była w Anglii nadal przeprowadzana. W XVII w. była ona stosowana również $\mathrm{w}$ angielskich koloniach, jak choćby na Bermudach oraz w Connecticut i Virginii ${ }^{164}$.

Próby zimnej wody zakazano w Anglii dopiero w 1712 r., a każdego, kto by ją odtąd usiłował przeprowadzić, ostrzegano, że jeśli zrobi „użytek $\mathrm{z}$ takowego eksperymentu, a poddana mu osoba poniesie $\mathrm{w}$ jego następstwie śmierć, wszyscy, którzy doprowadzili do tego, zostaną uznani winnymi morderstwa z premedytacją i [...] ani księga króla Jakuba, ani inne wcześniejsze precedensy nie uchronią ich przed stryczkiem"165. Mimo tego zakazu w 1717 r. w Leicesterze dokonano pławienia dwóch kobiet - matki i córki, które miały pływać na wodzie niczym „korek, jak kawałek papieru lub też pusta baryłka, pomimo, że ze wszystkich sił starały się utonąć" ${ }^{166}$. Do procesu jednak nie doszło.

We Francji parlament paryski już w 1603 r. podjął decyzję o zakazie stosowania próby wody jako metody postępowania dowodowego $\mathrm{w}$ procesach o czary ${ }^{167}$. Mimo to parlament musiał interweniować w 1623 r., ponieważ w północno-wschodniej Francji lokalni sędziowie nadal akceptowali zwyczaj pławienia osób oskarżanych o przestępstwo czarostwa ${ }^{168}$. Efektem było nie tylko ukaranie tych sędziów, ale także wprowadzenie rok później nakazu (spowodowanego i innymi nadużyciami) automatycznych apelacji

163 M. Gaskill, Crime and mentalities in early modern England, Cambridge 2000, s. 118 .

164 Ibidem; W. Rummel, R. Voltmer, op. cit., s. 47.

165 R. H. Robbins, op. cit., s. 249.

166 Cyt. za: ibidem.

167 R. Mandrou, Die französischen Richter und die Hexenprozesse im 17. Jahrhundert, w: Die Hexen der Neuzeit. Studien zur Sozialgeschichte eines kulturellen Deutungsmusters, Hrsg. C. Honegger, Frankfurt am Main 1978, s. 312; J. Grimm, Deutsche Rechtsalterthümer, Göttingen 1854, s. 925. W przypisie 2 autor ten podał, że nastąpiło to dwa lata wcześniej - 1 grudnia $1601 \mathrm{r}$.

168 W. Monter, Witch trials in continental Europe, 1560-1660, w: B. Ankarloo, S. Clark, W. Monter, Witchcraft and magic in Europe. The period of witch trials, London 2002, s. 41. 
od wyroków sądów lokalnych do parlamentu paryskiego ${ }^{169}$. Natomiast zakaz stosowania pławienia w całej Francji został wprowadzony w $1641 \mathrm{r}$. Rok później, 10 sierpnia 1642 r., parlament paryski wydał wyrok śmierci na sędziów z Braugelon za poddanie kobiety oskarżonej o czary próbie wody, w trakcie której zmarła ${ }^{170}$. Mimo zakazu nadal pławiono w Ardenach w 1644 r. ${ }^{171}$ Jeszcze w 1696 r. parlament w Dijon musiał dyscyplinować podległych mu sędziów niższych instancji, którzy próbę wody nadal kazali przeprowadzać $^{172}$.

Ograniczenia w stosowaniu próby zimnej wody w procesach o czary lub całkowity jej zakaz wychodziły zazwyczaj „od góry”, czyli od władców terytorialnych czy instytucji centralnych, jak widać to choćby na przykładzie Francji. Podobnie było w Bawarii, w której próby pławienia (oraz próby gorącego żelaza), jako zabobonnej, zakazał w 1622 r. jej władca książę Maksymilian $\mathrm{I}^{173}$. W przypadku Prus Książęcych zakaz wykorzystywania pławienia został także wprowadzony z inicjatywy władcy. Dnia 4 kwietnia 1679 r. elektor brandenburski Fryderyk Wilhelm wystawił pismo skierowane do rządu pruskiego, w którym zabronił używania próby wody w procesach o czary. Dwa miesiące później, 22 czerwca 1679 r., rząd pruski w Królewcu w imieniu elektora poinformował wszystkich starostów o obowiązującym odtąd zakazie stosowania pławienia w przypadkach oskarżeń o czary. Wynikało to z tego, że wiele osób zaliczających się do szlachty uznawało - pod pozorem zbierania dowodów winy oskarżonych o czary - zasadność „rzucania do wody”. Kontrastowało to z poglądem elektora brandenburskiego, który sprzeciwiał się posługiwaniu się próbą wody jako niewiarygodną. Starostom polecono opublikować zakaz, tak aby dowiedziała się o nim nie

169 A. Soman, The Parlament of Paris and the Great Witch Hunt (1565-1640), "The Sixteenth Century Journal” 1978, vol. 9, no. 2, s. 33.

170 R. H. Robbins, op. cit., s. 248.

171 W. Monter, Witchcraft trials in France, w: The Oxford handbook of witchcraft..., s. 226.

172 R. Mandrou, op. cit., s. 313.

173 S. Riezler, op. cit., s. 217; R. Bartlett, op. cit., s. 149. 
tylko miejscowa szlachta, lecz także mieszkańcy miasteczek i wsi. Osobom łamiącym te wytyczne władca pruski groził surowymi karami ${ }^{174}$.

Zakaz pławienia domniemanych czarownic początkowo nie był jednak przestrzegany przez przedstawicieli pruskiej szlachty. Jeden z nich, Hans Rudolph von Reppichau, twierdząc, że ma pewne dowody, nakazał w 1685 r. aresztować i pławić kobietę, którą przed kilku laty powołały inne skazane na stos kobiety. Dowiedziawszy się o tym, władca pruski osobiście wysłał list do Reppichaua, w którym poinformował go, że czarowników i czarownic nie można poddawać próbie wody. Osoby te należy przesłuchiwać zgodnie z przepisami zawartymi w prawie krajowym (Landrechcie) ${ }^{175}$. Zakaz stosowania próby zimnej wody i próby gorącego żelaza został ostatecznie wprowadzony do pruskiego Landrechtu w 1685 r. Za jego łamanie groziły surowe kary ${ }^{176}$.

\section{Próba zimnej wody w „wieku światła”}

Wiara w oczyszczającą moc poświęconej wody była powszechna także w czasach oświecenia. W miarodajność wyników pławienia wierzono nadal w wielu krajach ${ }^{177}$. W związku z tym w dalszym ciągu przeprowadzano próbę zimnej wody - przed procesami o czary lub w ich trakcie - choć ze

174 Geheimes Staatsarchiv Preußischer Kulturbesitz w Berlinie-Dahlem (GStAPK), XX. HA.: Etats Ministerium [EM] 33 h [Gotteslästerung, Hexerei, Zauberei], EM 33h, nr 119, k. 3r-4r.

175 J. Wijaczka, Procesy o czary w Prusach Ksiązęcych (Brandenburskich) w XVI-XVIII wieku, Toruń 2007, s. 174. List elektora z 18 maja 1685 r.

${ }_{176}$ Churfürstlich Branderburgisches Revidiertes Land $=$ Recht des Herzogthumbs Preußen. Worin die kleiner Buchstaben des textes dasjenige, so au $\beta$ dem vorigen Land-Recht beybehalten, die grössere Buchstaben aber, was in der Revision geändert oder hinzugethan anzeigen, Königsberg 1685 , s. 857, artykuł 2, paragraf $1:$ „, [... vilweniger auf irkaine Wasser $=$ oder heissen Eisens Prob, als welche Proben in diesem Herzogthumb bey willkührlicher Straff gantz und gar verbotten sind und nochmahlen hiermit verbotten werden".

177 B. P. Levack, Polowanie na czarownice w Europie wczesnonowożytnej, thum. E. Rutkowski, Wrocław-Warszawa-Kraków 1991, s. 259. 
znacznie mniejszą intensywnością niż w XVII w. ${ }^{178}$ Przekonanie o wiarygodności różnych prób mających dowieść winy lub niewinności oskarżonej osoby wciąż było rozpowszechnione nawet wśród teoretycznie „oświeconych” osób. Przykładem francuski filozof i prawnik Charles Louis de Secondat, baron de La Brède et de Montesquieu, znany jako Monteskiusz (1689-1755). W wydanej w 1748 r. pracy Esprit des lois Monteskiusz bronił sądów bożych, przede wszystkim pojedynków i próby ognia ${ }^{179}$.

Wątpliwości związane z przeprowadzaniem próby zimnej wody stawały się jednak coraz popularniejsze wśród europejskich prawników i sędziów, jak choćby w Rzeczypospolitej, gdzie w 1702 r. sąd asesorski koronny zakazał jej przeprowadzania sądowi w Łęczycy, a na dodatek jego członkowie za dopuszczenie do pławienia zostali pozbawieni stanowisk ${ }^{180}$. Przeciwko wykorzystywaniu próby zimnej wody opowiedział się też sędzia z Chełmna, Jakub Antoni Czechowicz (1681-1747), autor Praktyki kryminalnej, będącej jedynym opracowaniem prawa karnego w Polsce do czasu rozbiorów. Wydana drukiem w 1769 r., a więc dopiero 22 lata po śmierci autora, praca ta odzwierciedlała praktykę dnia codziennego stosowaną w sądownictwie miast polskich w pierwszej połowie XVIII w. ${ }^{181}$ Sędzia Jakub Antoni Czechowicz opowiadał się przeciwko pławieniu, twierdząc: „[...] krótko z authorami niżej wyrażonemi odpowiadam, że takowa exploracya przez zimną wodę nie jest sposób doskonały i prawdziwy poznania czarownic, i nie tylko na takie magistraty i urzędy a sede Apostolica zaszła exkomunika, którzy się do takowych udają superstycyi, ale i doktorowie prawa negative w tym odpowiadają"182.

Znacznie wcześniej w wiarygodność próby wody nie wierzyli już radcy elektora Hanoweru. Potwierdza to przypadek z 1707 r. W pewną

178 Späte Hexenprozesse. Der Umgang der Aufklärung mit dem Irrationalen, Hrsg. W. Behringer, S. Lorenz, D. R. Bauer, Bielefeld 2016.

179 H. Nottarp, op. cit., s. 394.

180 J. Rafacz, Sprawy karne w sądach miejskich w epoce nowożytnej, „Kwartalnik Historyczny” 1933, nr 47/3, s. 568.

181 Z. Zdrójkowski, "Praktyka kryminalna” Jakuba Czechowicza. Jej źródta i system na tle rozwoju wspótczesnego prawa karnego zachodniej Europy, Toruń 1949, s. 111.

182 J. Czechowicz, Praktyka kryminalna to jest wzór rozważanego i porządnego spraw kryminalnych sadzenia, Chełmno 1769, s. 111-112. 
lipcową niedzielę w trakcie nabożeństwa mieszkanka wsi Drebber, w elektoracie Hanoweru, wdowa Catharina Wöhler udała się nad położony w lesie staw, nad jego brzegiem sama skrępowała sobie najpierw nogi, a potem dłonie, po czym sturlała się z brzegu do wody. Świadkami tego wydarzenia miało być wiele osób. Kobieta utrzymywała się na powierzchni wody, a po pewnym czasie sama wydostała się na brzeg. Wróciła do wsi, ale jej pasierb nie chciał jej wpuścić do domu.

O tym wydarzeniu miejscowy starosta poinformował sędziego amtu Diepholz, chcąc wiedzieć, czy ma zająć się tą sprawą i czy powinien dostarczyć kobietę do sądu. Takie polecenie otrzymał, 20 sierpnia doszło bowiem do przesłuchania Catahriny Wöhler. Zeznała w jego trakcie, że ma prawie 70 lat, a wdową jest od niecałych 14 lat. Opowiedziała sędziemu, jak się związała i dostała do wody, a następnie z niej wyszła. Podała też nazwiska kliku osób, które ją podczas tych czynności obserwowały. Sędzia chciał wiedzieć, dlaczego to uczyniła. Odparła, że chciała pokazać ludziom, iż nie jest czarownicą, o co podejrzewano ją we wsi. Na pytanie, czy wierzy w to, że związana osoba utrzymująca się na powierzchni wody jest czarownica, kobieta nie udzieliła jednoznacznej odpowiedzi. Przyznała jednak, że powszechne jest przekonanie, że taka osoba jest czarownicą, a prawdziwy chrześcijanin się topi. Zeznanie to trafiło do Hanoweru, do jednego z elektorskich radców, który polecił sprawdzić, czy kobieta jest zdrowa na umyśle i czy dysponuje jakimiś środkami finansowymi. Ze starostwa odpowiedziano, że jest zdrowa. Poinformowano też, że nie dysponuje żadnym majątkiem. W efekcie radca elektorski skazał ją za przeprowadzenie „zabobonnej” próby wody na pięć dni więzienia, które Wöhler odsiedziała między 10 a 14 października 1707 r. ${ }^{183}$ Można dodać, że w trakcie procesów o czary prowadzonych przez sąd w Diepholz w latach poprzednich oskarżone osoby prosily o próbę wody, aby dowieść swej niewinności ${ }^{184}$.

W 1711 r. w Dubnie na Wołyniu na żądanie szlachcica Fiodora Kownackiego miejscowy magistrat przeprowadził z kolei pławienie 10 mieszkanek miasta oskarżonych przez niego o sprowadzenie suszy. Dzięki zabiegom

183 Wilhelm, Hexen = Prozesse aus dem 17. Jahrhundert. Mit höherer Genehmigung aus dem Archiv des Königlich Hannoverschen Amtsgerichts Diepholz, Hannover 1862, s. 87-91.

184 Ibidem, s. 18-19. 
małżonków mieszczanek nie doszło jednak do dalszego postępowania sądowego $^{185}$.

Na Węgrzech najwięcej prób zimnej wody wykonano w latach 1690$-1730^{186}$. Natomiast między 1740 a 1746 r. pławienie (w rzekach) odbyło się w miastach Nagybánya (Baia Mare, Frauenbach), Kecskemét i Kiskunhals. Dochodziło do tego w tamtejszych gminach kalwińskich ${ }^{187}$. W Siedmiogrodzie w latach 1740-1768 próbie wody poddanych zostało 40 osób ${ }^{188}$. W latach 30. XVIII w. próbę pławienia wykonywano w amerykańskim stanie Connecticut ${ }^{189}$. Również w Anglii, jeszcze w połowie XVIII w., mimo zakazu pławienia zdarzało się, że przeprowadzano tę próbę, choć już nie na polecenie sądów. W miejscowości Frome w hrabstwie Somerset w 1731 r. 200-osobowy tłum obserwował próbę wody dokonanej na kobiecie, która po jej przeprowadzeniu padła ofiarą linczu ${ }^{190}$. Dnia 11 lipca 1736 r. nielegalne pławienie zastosowano we wsi Twyford w hrabstwie Leicestershire ${ }^{191}$. W 1751 r. w Hertfordshire tłum wyciągnął z przytułku Ruth Osborne i jej męża, po czym rozebrał ich do naga, przywiązał ręce do nóg i zaciągnął nad rzekę $^{192}$. W efekcie oboje stracili życie, w związku z czym na karę śmierci skazano kominiarza Thomasa Colleta, który zorganizował pławienie małżeństwa ${ }^{193}$. Jeszcze w latach 60. XVIII w. dwóch domorosłych łowców

185 R. Zguta, The ordeal by water..., s. 228.

186 P. Tóth, River ordeal..., s. 141-142 i aneks nr 2.

187 Idem, The decriminalization of magic and the fight against superstition in Hungary and Transylwania, 1740-1848, w: Witchcraft and demonology in Hungary and Transylvania, eds. G. Klaniczay, E. Pócs, Cham 2017, s. 302-303.

188 Ibidem, s. 303.

189 W. Behringer, op. cit., s. 146.

190 M. Gaskill, Crime..., s. 82.

191 W. Behringer, op. cit., s. 186; H. Juxon, A sermon upon witchcraft. Occasion'd by a late illegal attempt to discover witches by swimming. Preache'd at Twyford, in the county of Leicester, July 11, 1736, London 1736.

192 B. P. Levack, Polowanie na czarownice w Europie wczesnonowożytnej, tłum. E. Rutkowski, z dodatkiem Katalogu magii Mnicha Rudolfa, zabytku z XIII w., tłum. E. Karwot, Wrocław-Warszawa-Kraków 1991, s. 259.

193 O. Davies, The world of popular magic, w: The Oxford illustrated history..., s. 194. 
czarownic krążyło po hrabstwie Leicestershire i doprowadziło do pławienia wielu starych kobiet ${ }^{194}$.

Utrzymująca się w społeczeństwie europejskim wiara w wiarygodność pławienia sprawiała, że próba zimnej wody nadal była stosowana w niektórych słabo rozwiniętych gospodarczo i kulturalnie regionach w Europie jeszcze w ostatnich dziesięcioleciach XVIII w. Przykładem wydarzenia, do których doszło 13 marca 1779 r. we wsi Osowo (Ossowo), w powiecie tucholskim. Mieszkańcami tej wsi byli przedstawiciele drobnej szlachty ${ }^{195}$, a wieś była podzielona na 12 cząstek $^{196}$. Jedna z nich od 1767 r. należała do Andrzeja Żabińskiego, który przyjął do swego gospodarstwa, jako zagrodnika, Mathiasa Kopkę ${ }^{197}$. Po pewnym czasie żona Żabińskiego doszła do wniosku, że odkąd Kopkowie zamieszkali w ich gospodarstwie, zaczęły dotykać ich różne niewielkie nieszczęścia. Zaczęła podejrzewać, że jedno z Kopków jest czarownicą/czarownikiem, które za pomocą czarów mści się za drobne kłótnie i nieporozumienia pojawiające się między rodzinami. W tym samym czasie Agnieszka, córka Żabińskich, zaczęła utykać na prawą nogę, odczuwając przy tym bardzo silny ból w kolanie i udzie ${ }^{198}$. Lekarz stwierdził, że ból jest pochodzenia artretycznego, związanego z podagrą. Jednak matka Agnieszki uznała, że lekarz się pomylił, a prawdziwą przyczyną choroby były zadane jej córce, przez żonę Kopki, czary. Nie tylko zaczęła rozpowiadać w całej wsi, że Kopkowa jest czarownicą, ale również doprowadziła do tego, że sołtys postanowił poddać oskarżaną o czary kobietę pławieniu. Kopkowa została pochwycona przez Andrzeja Żabińskiego, jego syna Franciszka i kilku innych mężczyzn, którzy siłą zawlekli ją nad znaj-

194 M. Gaskill, Crime..., s. 82.

195 Stownik geograficzny Królestwa Polskiego i innych krajów stowiańskich, t. 7, red. B. Chlebowski, W. Walewski, Warszawa 1886, s. 655.

196 M. Bär, Der Adel und der adlige Grundbesitz in Polnisch-Preussen zur Zeit der preussischen Besitzergreifung. Nach Auszügen aus den Vasallenlisten und Grunbüchern, Leipzig 1911, nr 1239, s. 123.

197 W 1765 r. gbur Matusz Kopka mieszkał we wsi Szawda - należącej do starostwa w Brodnicy, gdzie miał „chałupę w szachulec starą, stodołę i szopę w słupy i dyle; dachy reparacyi potrzebne”. Posiadał konia i obsiewał 32 morgi. Czy to jednak ta sama osoba, trudno jednoznacznie powiedzieć. Lustracja województw Prus Królewskich 1765, t. 2: Województwo chetmińskie, cz. 1: Ziemia michatowska, wyd. J. Dygdała, Toruń 2007, s. 10.

198 H. L. Fischer, Das Buch vom Aberglauben, Bd. 1, Leipzig 1791, s. 303. 
dujący się w pobliżu wsi staw, gdzie musiała się rozebrać do koszuli. Żona Żabińskiego skropiła staw święconą wodą, a jej syn związał Kopkowej ręce i stopy na krzyż postronkami sporządzonymi ze słomy. Gdy została wrzucona do wody, postronki się rozwiązały i kobieta wyszła na brzeg. Ponownie ją związano i wrzucono do wody. Tym razem także znowu wydostała się na brzeg. To sprawiło, że nikt z obecnych nie miał już wątpliwości, że pławiona kobieta jest czarownicą ${ }^{199}$. Jej mąż, który spędził z nią 21 lat w związku i nie wierzył w to, aby była czarownicą, nie widział jednak innego sposobu dowiedzenia jej niewinności, jak jeszcze jedno - trzecie - przeprowadzenie próby wody. Dogonił więc powracających do wsi uczestników i świadków pławienia. Zaczął ich przekonywać, aby jeszcze raz związać jego żonę - tym razem solidniej, by następnie wrzucić ją do wody na środek stawu. Tak się też stało. Obaj Żabińscy wzięli kobietę pod ramiona i stojąc na brzegu, wrzucili ją do wody. Jeden z mężczyzn za pomocą długiego kija popychał oskarżoną w kierunku środka stawu. Kobieta początkowo pływała na brzuchu po wodzie, a po pewnym czasie udało się jej wyswobodzić z krępujących ją więzów. Tym razem zgromadzeni uznali, że mogą na rzekomej czarownicy dopuścić się innych okrucieństw. Członkowie rodziny Żabińskich dotkliwie pobili kobietę, a następnie zażądali, aby „odczarowała” ich córkę Agnieszkę. Na koniec stwierdzili, że Kopkowa nie ma prawa pojawić się już nigdy więcej we wsi. Zmaltretowana kobieta błagała oprawców o miłosierdzie i prosiła, aby pomogli jej podnieść się z ziemi. Zamiast tego jeden z obecnych zaczął ją ponownie okładać kijem tak długo, aż ten się złamał. Mężczyzna pozostałym mu w ręku kawałkiem uderzył kobietę w twarz i rzekł: „Wstawaj bestio i ubierz się"200. Kobieta w efekcie okrutnego pobicia zmarła.

Trzeba dodać, że wiara w czary i czarownice oraz moc pławienia na Pomorzu w końcu XVIII w. była wśród tamtejszej ludności powszechna. Potwierdzają to nie tylko wyżej opisane wydarzenia, ale także te, które rozegrały się w okolicach Bytowa w 1787 r. Doszło wówczas do fali rzekomych opętań przez diabła, co w efekcie wywołało panikę w licznych wsiach i miasteczkach. Zaczęto szukać czarownic, a jedną z dróg do tego prowadzących

199 Ibidem, s. 303-304.

200 Ibidem, s. 305. 
miała być właśnie próba wody. $\mathrm{O}$ zgodę na jej przeprowadzenie zwrócił się do sądu w Bytowie katolicki proboszcz we wsi Parchowo - Rogowski. Był przekonany o tym, że jest to najlepszy środek przynoszący rozpoznanie wśród mieszkańców jego wioski czarowników i czarownic ${ }^{201}$. Chciał również osobiście być obecny w trakcie przeprowadzania tej próby, ale sąd na pławienie zgody nie udzielił.

Mieszkańcy Pomorza nie byli osamotnieni. Prośby oskarżonych kobiet o podanie ich próbie wody, aby dowieść swej niewinności, zdarzały się w końcu XVIII w. także w Anglii ${ }^{202}$. W 1785 r. Sara Bradshow z Mears Ashby w hrabstwie Northamptonshire dobrowolnie poddała się pławieniu - w celu udowodnienia mieszkańcom wsi, w której mieszkała, że zarzut uprawiania przez nią czarów jest nieprawdziwy ${ }^{203}$.

\section{Uwagi końcowe}

Dlaczego próba zimnej wody, mimo że formalnie zakazana tak w prawie kościelnym, jak i w prawie świeckim kilku państw europejskich, funkcjonowała w czasach wczesnonowożytnych w trakcie procesów o czary?

Fiński historyk Heikki Pihlajamäki uznał, że stało się tak z powodu stosowania w ówczesnym prawie karnym postepowania dowodowego ${ }^{204}$. Rzeczywiście, pławienie, jeśli brakowało innych dowodów winy, stawało się takim dowodem. Tak było w procesie, który wytoczono w 1654 r. nieznanej z nazwiska kobiecie z Todtenhausen w księstwie Minden. Kobieta ta została obwiniona o otrucie męża za pomocą czerwonego proszku. Uznano

201 D. G. Scheerbarth, Diplomatische Nachricht von der im Jahr 1787 in und um dem Königl. Preuß. Pommerschen Domainen Justizamte Bütow, gerichtlich untersuchten vorgegebenen Hexengeschichte, nebst dem dadurch auf höhern Befehl veranlaßten Gutachten und Replik, herausgegeben mit drey gegen diesen Aberglauben gehaltenen Predigten, Stettin 1793, s. 27.

202 G. L. Kittredge, Witchcraft in Old and New England, Cambridge 1929 (reprint: 2013), s. 236.

203 D. Pickering, Lexikon der Magie und Hexerei, übers. R. van Treeck, Augsburg 1999, s. 275.

204 H. Pihlajamäki, op. cit., s. 53. 
ją za czarownicę i skazano na karę śmierci, a koronnym dowodem jej winy było to, że w trakcie próby zimnej wody cały czas utrzymywała się na powierzchni ${ }^{205}$.

Przy użyciu pławienia sędziowie poszukiwali więc dowodu winy, jeśli go nie uzyskali wcześniej. Próba ta była stosowana też po to, aby zebrać odpowiednią liczbę dowodów i poszlak ${ }^{206}$, które pozwoliłyby wprowadzić tortury ${ }^{207}$. Ich użycie było w praktyce niezbędne, aby uzyskać przyznanie się osoby oskarżonej o czary do zarzucanych jej czynów ${ }^{208}$.

Próba wody nie zawsze jednak odgrywała decydującą rolę w przebiegu procesu o czary. Widać to na przykładzie biskupstwa Osnabrück. O ile w dwóch powiatach należących do tego biskupstwa - Vöredn i Wittlage w których liczba ofiar procesów o czary była najwyższa w całym biskupstwie, próba wody została przeprowadzona jedynie dwa razy ${ }^{209}$, o tyle w samym Osnabrücku stanowiła konieczny warunek do dalszego postępowania procesowego. Tylko wtedy bowiem, gdy wypadała negatywnie dla pławionej osoby, można ją było przekazać na tortury w ręce kata ${ }^{210}$. Zapewne $\mathrm{z}$ tego powodu w latach 1561-1639 w procesach przeprowadzonych tylko w mieście Osnabrück wydano wyroki śmierci na 276 kobiet i dwóch mężczyzn,

205 E. A. F. Culemann, 5. Abtheilung Mindischer Geschichte. Aus beglaubten Nachrichten zusammen gebracht. Darinnen kürtzlich erzehler wird, Was sich unter der Regierung sechs Bischöfe... Vom Jahr 1554 bis 1713 im Stift Minden ... zugetragen..., Minden 1748, s. 239; por. H. Nottarp, op. cit., s. 205.

206 Przez poszlaki rozumiano fakty, które nie są ważne dla konkretnej sprawy karnej, lecz można na ich podstawie wysnuwać wnioski o prawdziwości ważnych zdarzeń; J. J. Bossowski, Ewolucja postepowania dowodowego w procesie karnym. Od pojedynków sadowego i Sąów Bożych do psychologicznej oceny zeznań i dowodów rzeczowych, Poznań 1924, s. 10, przypis 1.

207 H. Pihlajamäki, op. cit., s. 52; R. Zagolla, op. cit., s. 283; J. Lehrmann, op. cit., s. 47.

${ }^{208}$ L. H. Willumsen, Witches of the North..., s. 269.

${ }^{209}$ W. Komber, Hexenprozess, Zauber und Schadenzauberglaube im alten Amt Wittlage, w: Van Hexen un Düvelslüden. Über Hexen, Zauberei und Aberglauben im niederländischdeutschen Grenzraum, Hrsg. M. Saatkamp, D. Schlüter, Entschede 1995, s. 114.

${ }^{210}$ H. J. Stebel, op. cit., s. 98. 
a w latach 1538-1699 w powiatach należących do tegoż biskupstwa stracono już tylko 49 kobiet i czterech mężczyzn ${ }^{211}$.

Próbę wody stosowano na różnych etapach oskarżenia i procesów o czary, w zależności od regionu i sądu. W niektórych regionach była przeprowadzana najczęściej na żądanie oskarżonych, w innych zaś sędziowie wykorzystywali ją, aby nakłonić w ten sposób do przyznania się do szkodliwych czarów i współpracy z diabłem ${ }^{212}$. Niektórzy z oskarżonych na samą wieść, że zostaną poddani pławieniu, zaczynali zeznawać i przyznawać się do bycia czarownicą/czarownikiem ${ }^{213}$.

$\mathrm{Na}$ Litwie pławienie przeprowadzano w trakcie, a nie przed rozpoczęciem procesu, a zlecał je sąd ${ }^{214}$. W Polsce z kolei nie było jednolitej zasady stosowania tej próby w procesach o czary, a sięganie po nią warunkowały: tradycja panująca w danym regionie, mentalność właścicieli wsi i miasteczek oraz przekonania sędziego i członków rady miejskiej. Najczęściej, jak się wydaje, pławienie przeprowadzano jeszcze przed wniesieniem formalnego oskarżenia i rozpoczęciem procesu na wniosek bądź na podstawie decyzji: 1) oskarżyciela; 2) osoby oskarżanej (a czasem jej bliskich), która chciała dowieść swojej niewinności i nie dopuścić do wszczęcia procesu z bardzo prawdopodobnym użyciem tortur; 3) właściciela wsi lub miasteczka w celu sprawdzenia, czy osoba pomawiana rzeczywiście jest czarownicą; 4) rady miejskiej, do której należało, zgodnie z podziałem czynności, wstępne rozpoznanie sprawy kryminalnej i przekazanie jej do sądu wójta i ławy; 5) sądu w trakcie procesu ${ }^{215}$.

$\mathrm{Na}$ terenie samodzielnego opactwa St. Maximin w Rzeszy próba zimnej wody była z kolei przeprowadzana dopiero w momencie, kiedy oskarżona osoba nie chciała przyznać się do bycia czarownicą/czarownikiem - nawet w trakcie okrutnych tortur. Dopiero wówczas taką osobę,

211 G. Wilbertz, Hexenprozesse und Zauberglaube im Hochstift Osnabrück, „Osnabrükker Mitteilungen” 1978, Bd. 84, s. 34-41.

212 Ch. Gerst, op. cit., s. 216-217.

213 L. H. Willumsen, Witchcraft trials in Finnmark Northern Norway, trans. K. Edwardsen, Bergen 2010, s. 27-28.

214 J. Wijaczka, Próba zimnej wody (ptawienie)..., s. 77.

215 Ibidem, s. 90-95. 
wymęczoną - fizycznie i psychicznie - torturami, wrzucano związaną do wody, pod którą wpychano ją wielokrotnie za pomocą drąga ${ }^{216}$.

Moim zdaniem na powszechność stosowania próby zimnej wody w procesach o czary we wczesnonowożytnej Europie nie wpływała profesjonalizacja zawodu sędziego, ponieważ trudno o tym mówić choćby w przypadku Rzeczypospolitej ${ }^{217}$. Realne znaczenie miało to, że w chrześcijańskim społeczeństwie bardzo mocna była wiara w święconą wodę, a także w to, iż Bóg nie pozwoli skrzywdzić niewinnej osoby. W 1704 r. oskarżona o uprawianie czarów żona zagrodnika Pawła Pomyjskiego ze wsi Rudno (pow. Kwidzyn) prosiła członków sądu sołtysiego, by w przypadku podjęcia decyzji o poddaniu jej próbie wody odbyła się ona w poświęconej wodzie. Chciała też, by trzymano ją w trakcie próby na poświęconej linie ${ }^{218}$. Przykłady można mnożyć.

Bez wątpienia na powszechne wykorzystywanie zimnej wody w procesach o czary w krajach katolickich wpływało też lekceważenie przez biskupów zakazu udziału duchownych w tych próbach. Nie pomogło nawet $\mathrm{w}$ tej kwestii to, że w połowie XVII w. papiestwo postanowiło oficjalnie zaaprobować i upowszechnić ordynację postępowania w procesach o czary, tzw. Instrukcję rzymską, w której m.in. ponownie zabroniono posługiwania się próbą zimnej wody ${ }^{219}$. Ponieważ jednak papiestwo nie zdecydowało się na stosowanie surowych sankcji za jej nieprzestrzeganie, niewielu liczyło

216 R. Voltmer, H. Eiden, Rechtsnormen, Gerichts- und Herrschaftspraxis bei Hexereiverfahren in Lothringen, Luxemburg, Kurtrier und St. Maximin während des 16. und 17. Jahrhunderts, w: Hexenwahn. Änste der Neuzeit. Begleitband zur gleichnamigen Ausstellung des Deutschen Historischen Museums, Hrsg. R. Beier-de Haan, R. Voltmer, F. Irsigler, Berlin 2002, s. 69.

217 Zob. m.in. M. Pilaszek, W poszukiwaniu prawdy. O dziatalności sądów kryminalnych w Koronie XVI-XVIII w., „Przegląd Historyczny” 1998, t. 139, z. 3, s. 361-381.

218 J. Alexy, Die Geschichte des Dorfes Adl. Rauden, Kreis Marienwerder: geschrieben zum 550 jährigen Jubiläum des Ortes und die Geschichte der Kirchengemeinde Rauden: verfasst zum 150 jährigen Jubiläum der Kirche, Schwetz a. W. 1909, s. 12.

219 Na temat tejże instrukcji zob. R. Decker, Hintergrund und Verbreitung des Drucks der Römischen Hexenprozess-Instruction (1657), „Historisches Jahrbuch” 1998, Bd. 118, s. 277-286; idem, Gerichtsorganisation und Hexenprozeßrecht der römischen Inquisition. Neue Quellenfunde zu Theorie und Praxis, w: Hexenprozesse und Gerichtspraxis, Hrsg. H. Eiden, R. Voltmer, Tier 2002, s. 455-473. 
się z jej postanowieniami. Przykładem cystersi w Oliwie, którzy 13 grudnia 1663 r. nakazali katu poddać pławieniu oskarżoną o czary Urszulę, a w styczniu 1644 r. inne dwie kobiety ${ }^{220}$.

Jak wynika $\mathrm{z}$ dotychczasowej literatury przedmiotu, próba zimnej wody była najbardziej popularna w krajach Rzeszy (choć nie we wszystkich była praktykowana, nie było jej m.in. w księstwach na terytorium Turyngii ${ }^{221}$ i państwie polsko-litewskim. Nie przeprowadzano jej natomiast w Hiszpanii, we Włoszech i na południu Francji ${ }^{222}$. Niezbyt często stosowano ją w Szwecji, Finlandii ${ }^{223}$ czy też w należącej do Habsburgów prowincji Vorarlberg ${ }^{224}$. Trzeba jednak zauważyć, że w innych regionach rządzonych przez Habsburgów - mimo funkcjonującego tam oficjalnego zakazu - próba wody była wykonywana na polecenie sędziów. Takie z punktu widzenia obowiązującego prawa nielegalne pławienie w 1676 r. przeprowadzono z polecania sędziego Georga von Villa w miasteczku Friedau w Dolnej Styrii (obecnie: Ormož, Słowenia). Sędzia nakazał pławienie sześciu kobiet w rzece Drau, nad którą miasteczko było położone ${ }^{225}$.

Zdarzało się, że pławienie odgrywało inną rolę. W Bazylei w latach 1541-1634 próba zimnej wody była stosowana jako pewien rodzaj kary. Skazane już w procesie osoby wrzucano związane do przepływającego przez miasto Renu. Gdy wrzucona do wody osoba dopłynęła do określonego wcześniej miejsca, w którym oczekiwali na nią miejscowi rybacy, wyciągano ją, a jeśli jeszcze żyła, to ratowano, uznając, że kara została odbyta ${ }^{226}$.

220 Biblioteka Gdańska Polskiej Akademii Nauk, MS 68, Dantziger Historien, k. 109v; por. J. Alexy, op. cit., s. 11.

221 R. Füssel, Die Hexenverfolgungen im Thüringer Raum, Hamburg 2003, s. 164.

222 H. Pihlajamäki, op. cit., s. 42. Nie do końca wiadomo, czy była przeprowadzana w Danii. Nie wspomina o niej nic w wydanej cztery lata temu pracy Louise N. Kallestrup, Agents of witchcraft in early modern Italy and Denmark, New York 2015.

${ }^{223} \mathrm{Z}$ terenu Finlandii znany jest tylko jeden przypadek pławienia; H. Pihlajamäki, op. cit., s. 42.

${ }_{224}$ M. Tschaikner, Die Hexenverfolgungen in den österreichischen Herrschaften vor dem Arlberg, w: Hexenforschung aus österreichischen Ländern, Hrsg. H. Dienst, Berlin 2012, s. 72 .

225 F. Byloff, Hexenglaube und Hexenverfolgung in den österreichischen Alpenländern, Berlin-Leipzig 1934, s. 121.

226 Gottesurteil (Ordal), s. 1028. 
Mimo że pławienie w większości krajów europejskich (bez względu na wyznanie panujące w danym kraju), w których prowadzono procesy o czary, było teoretycznie nielegalne ${ }^{227}$, to dla większości mieszkańców wsi i miasteczek utrzymywanie się oskarżonej osoby na powierzchni wody stanowiło niezbity dowód, że ktoś taki jest czarownicą/czarownikiem. W efekcie tego rozpowszechnionego w całej Europie przekonania próba zimnej wody była używana jeszcze w XIX w., choćby na Ukrainie i w Gruzji ${ }^{228}$. Przykładem wydarzenia z 1836 r., dziejące się w - należącej wówczas do Prus - wsi Ceynowa (obecnie: Chałupy), gdzie kilku mieszkańców pławiło na wodach Zatoki Puckiej wdowę Krystynę Ceynową 229. Pławienie przetrwało, jak i wiara w czarownice, wśród mieszkańców wsi, których ogół uważał wdowę Krystynę Ceynowę za „niebezpieczną czarownicę, gdyż nigdy nie chodziła do kościoła, wrony siadały na jej kominie i była wszechwiedzącą, bo wiedziała o wszystkim, co o niej mówiono"230. Wiara zazwyczaj wygrywa $\mathrm{z}$ rozsądkiem.

Próbę zimnej wody trzeba również traktować jako torturę - fizyczną, a przede wszystkim psychiczną. Osobą „rzucaną” na wodę musiały targać ogromne emocje wynikające z obawy, czy pławienie przebiegnie dla niej korzystnie ${ }^{231}$. W prawie wszystkich przypadkach próba ta wypadała niepomyślnie. Musiał wiązać się z tym znaczący szok oskarżonych, zwłaszcza jeśli weźmie się pod uwagę to, że wielu wierzyło, iż poświęcona woda i Bóg nie pozwolą skrzywdzić niewinnej istoty.

227 P. Dinzelbacher, Swimming test, w: Encyclopedia of witchcraft. The western tradition, vol. 4: Q-Z, ed. R. M. Golden, Santa Barbara, California 2006, s. 1097.

228 R. Zguta, The ordeal by water..., s. 228-230; W. Behringer, op. cit., s. 222.

229 J. J. Bossowski, Sądy Boże na Pomorzu. Szkic etnograficzno-prawny, Poznań 1937, s. 20-21; N. Freytag, Witchcraft, witch doctors and the fight against "superstition" in nineteenth-century Germany, w: Witchcraft continued. Popular magic in modern Europe, eds. W. de Blécourt, O. Davies, Manchester-New York 2004, s. 29-32.

230 J. J. Bossowski, Sądy Boże na Pomorzu..., s. 31.

231 Na temat roli emocji, tak oskarżonych, jak i osób związanych w procesami o czary, zob. Emotions in the history of witchcraft, eds. L. Kounine, M. Ostling, London 2016, passim. 